\title{
The economic consequences of extending the use of fair value accounting in regulatory capital calculations
}

\author{
Justin Chircop \\ Lancaster University Management School, Lancaster University, UK \\ j.chircop1@lancaster.ac.uk \\ Zoltán Novotny-Farkas* \\ Lancaster University Management School, Lancaster University, UK \\ z.novotny-farkas1@lancaster.ac.uk
}

October 2016

\begin{abstract}
We investigate the economic consequences of the Basel III requirement to include unrealized fair value gains and losses on available-for-sale (AFS) securities in regulatory capital. Using data for U.S. banks we find negative market reactions around news indicating an increased likelihood of this regulatory change being implemented, consistent with increased regulatory costs. We also find that banks affected by this regulation reduce their investment in risky AFS securities relative to unaffected banks. This result suggests that extending the use of fair values for regulatory purposes reduces ex ante risk taking.
\end{abstract}

Keywords: Banks, Fair Value Accounting, Prudential Regulation, Regulatory Capital

JEL Classifications: G21, M41

\footnotetext{
*Corresponding author. We thank an anonymous reviewer, Jannis Bischof, Ulf Brüggemann, Brett Cantrell (discussant), Peter Fiechter (discussant), Christian Laux (discussant), Günther Gebhardt, Igor Goncharov, Robert Göx, Vasso Ioannidou, S.P. Kothari (the Editor), Ken Peasnell and seminar participants at Lancaster University, University of Zurich, the 2014 summer workshop of the Institute of Economics of the Hungarian Academy of Sciences in Budapest, the 2014 joint workshop of the Deutsche Bundesbank and the Research Task Force of the Basel Committee on Banking Supervision, and participants at the 2015 EAA Annual Congress, the 2015 AAA Annual Meeting, and the 2015 Journal of Accounting and Economics conference for their advice and helpful comments. All remaining errors are our own.
} 


\section{Introduction}

We examine the economic consequences of the implementation of a particular provision of Basel III in the U.S. that requires the inclusion of unrealized fair value gains and losses on investment securities in regulatory capital. Given the large size of interest rate sensitive assets in banks' investment portfolios, this requirement significantly increases the importance of fair value accounting for regulatory purposes. This regulatory choice involves an important tradeoff. On the one hand, fair values introduce volatility into regulatory capital that might unduly result in regulatory intervention. On the other hand, fair value-based capital adequacy requirements might reduce managerial incentives to take excessive risks (Dewatripont and Tirole, 1994). We empirically investigate this trade-off by analyzing stock market reactions and banks' investment behavior around the events leading up to this regulatory change.

Under the previous U.S. regulatory capital guidelines, unrealized fair value gains and losses on available-for-sale (AFS) debt securities were filtered out of Tier 1 capital, which is commonly referred to as the “Accumulated Other Comprehensive Income (AOCI) filter.”1 In June 2012, regulators issued three notices of proposed rulemaking (hereafter referred to as the "Proposal"), which, besides significant changes in the calculation of regulatory capital and risk weightings, proposed the removal of the AOCI filter for all banks subject to the new regulatory framework. ${ }^{2}$ Many market observers regarded “...the removal of the AOCI filter ...[as] the biggest single issue the industry is lobbying over in terms of financial regulation.”3 Following significant opposition from banks, the Final Rule, issued on July 2, 2013, includes an opt-out provision for non-advanced approaches banks (i.e., generally banks with an asset size less than $\$ 250$ billion) to make a one-time, irreversible election to continue with the

1 To be precise, AOCI also includes unrealized gains and losses on cash flow hedges, foreign currency translation adjustments, and employee benefit plan adjustments. However, for most sample banks the magnitude of these adjustments is negligible compared to the magnitude of unrealized gains and losses on available-for-sale securities.

2 All banks with total assets greater than $\$ 500$ million were subject to the proposed rules.

3 See the article in Risk magazine, "Banks fear capital swings if Basel III kills bond filter,” from March 04, 2013, citing Peter Sime, Head of Risk and Research at the International Swaps and Derivatives Association. 
previous regulatory treatment of unrealized gains and losses. If they do not elect to opt out, they will be required to include the AOCI in regulatory capital from January 1, 2015. In contrast, advanced approaches banks (generally banks with an asset size greater than $\$ 250$ billion) cannot opt out and have to include unrealized gains and losses in regulatory capital from January 1, 2014.

Banking industry representatives such as the ABA (2012) argue that the removal of the AOCI filter is likely to increase regulatory capital volatility that is not reflective of banks' true economic risk. In rising interest rate environments unrealized fair value losses on AFS securities can result in a substantial hit to banks' Tier 1 capital because offsetting economic gains on the liability side are not recognized. As a consequence, banks may be considered less than well-capitalized by the market and regulators. ${ }^{4}$ Anticipating the regulatory capital effects arising from the removal of the AOCI filter, banks may hold fewer interest rate sensitive assets or invest in securities with shorter maturities. Given that banks are important investors in long-term government and agency securities, this might heavily affect trading in these markets. Alternatively, banks may reclassify bonds from AFS to held-to-maturity (HTM) so that temporary changes in fair values are not recognized. However, because HTM bonds generally cannot be sold without tainting banks’ HTM portfolios, banks' flexibility to use such securities for liquidity management would be reduced. Ultimately, this might affect their ability to lend. ${ }^{5}$

In contrast, regulators argue that the removal of the AOCI filter results in a regulatory framework that is more reflective of banks' risk, particularly credit risk. Indeed, in the fourth

4 A simulation exercise of the ABA (2012, p. A-8) indicates that if the AOCI filter were removed, a number of U.S. banks could fall below the well-capitalized standard in a rising interest rate environment.

5 For example, banks might reduce loan commitments extended to firms because they are less able to provide liquidity on demand when firms draw on the loan (Kashyap et al., 2002). 
quarter of 2008, the ten largest banks ${ }^{6}$ in our sample accumulated $\$ 35.3$ billion of unrealized losses on their AFS securities, primarily due to changes in credit spreads, that were not reflected in their Tier 1 capital. $^{7}$ While this preferential regulatory treatment might have prevented banks from breaching regulatory thresholds ex post, it also potentially provided ex ante incentives for banks to invest in illiquid AFS securities with higher credit risk, which are the key source of procyclical asset declines. This argument is consistent with theoretical studies showing that historical cost-based capital requirements induce risk-shifting behavior (Dewatripont and Tirole, 1994; Lu et al., 2012). In turn, extending the use of fair values in regulatory capital calculations would mitigate risk-shifting incentives ex ante and improve regulatory discipline. Moreover, the countercyclical behavior of interest rates can have a further regulatory benefit. Specifically, since interest rates tend to fall in bad times, corresponding fair value gains could dampen the impact of falling asset prices. In good times, unrealized fair value losses due to the rise in interest rates can limit the risk-taking ability of banks (e.g., Xie, 2015).

We investigate whether these potential economic costs and benefits are reflected in stock market participants' expectations and bank managers' investment behavior. We start by examining stock market reactions to pronouncements leading up to the passage of the Final Rule. The sign and magnitude of capital market reactions will depend on the perceived likelihood that the Final Rule will be implemented and the trade-off between the perceived benefits of greater regulatory discipline in bank risk taking and the associated costs of the potentially higher likelihood of regulatory intervention. To the extent that investors perceive the removal of the AOCI filter, on average as costly, we should observe negative (positive)

6 The top ten banks represent about 82 percent of total assets in our sample.

On average, unrealized fair value losses represented $10.4 \%$ of Top 10 banks' Tier 1 capital. For example, Citigroup reported an unrealized loss of $\$ 9.6$ billion on AFS securities representing $8.1 \%$ of its Tier 1 capital. State Street Corporation's unrealized loss amounted to $\$ 5.2$ billion or $36.9 \%$ of its Tier 1 capital. Only SunTrust banks had an unrealized gain of $\$ 0.9$ billion (5\% of Tier 1 capital). 
market reactions to events that increase (decrease) the likelihood of inclusion of AFS fair value gains and losses in regulatory capital. A key challenge of examining the economic consequences of any regulation using stock market reactions is to control for concurrent confounding events (e.g., Leuz 2007). In addition, our study faces the issue that the Final Rule was discussed and passed as a package, which makes it difficult to separate the effects of a particular provision. We address this issue in four ways: First, to control for general trends affecting the U.S. financial industry, we benchmark stock market reactions of banks to those of insurance companies, which also hold significant amounts of AFS securities but are unaffected by the regulation. Second, we compare abnormal returns of advanced approaches banks with non-advanced approaches banks on the Final Rule date, when only advanced approaches banks were affected by the mandatory AOCI filter removal, but other aspects of the regulation remained similar for the two groups of banks. Third, we undertake a crosssectional analysis to examine whether observed market reactions can be specifically attributed to the removal of the AOCI filter. Finally, to mitigate the concern that any cross-sectional findings are due to omitted correlated variables, we perform a bootstrapping analysis to benchmark our test results against results obtained on randomly selected non-event days.

Next, we study whether banks change their investment behavior in anticipation of the implementation of the Final Rule. Specifically, we examine whether banks reduce the maturity of their investment securities and the relative amount of their total securities classified as AFS, as argued by bank representatives. In addition, we test whether the use of fair value in regulatory capital calculations results in the reduction of banks' ex ante risk taking as predicted by theoretical literature (Dewatripont and Tirole, 1994; Lu et al., 2012). To this end, we examine whether banks reduce the level of illiquid assets in the AFS portfolio in anticipation of the AOCI filter removal. We choose illiquid assets because they tend to be 
riskier than the bulk of the AFS portfolio consisting of Treasury bonds and agency-backed securities. $^{8}$

Our setting is particularly conducive to investigating changes in banks' investment behavior. Specifically, we exploit the fact that the Proposal to remove the AOCI filter issued in June 2012 would have affected all banks (total assets greater than \$500 million), while the Final Rule issued in July 2013 provides an opt-out option for non-advanced approaches banks. ${ }^{9}$ In addition, small banks (total assets less than $\$ 500$ million) are not affected by any Basel III regulation. As a result, we have three groups of banks that are differently affected by the Proposal's and Final Rule's provisions regarding the removal of the AOCI filter. This allows us to utilize a differences-in-differences approach to compare changes in investment behavior for these three groups at different points in time.

We find statistically significant and negative (positive) market reactions to news that increased (decreased) the likelihood of AOCI filter removal, consistent with investors perceiving this regulatory provision as costly. In contrast, we do not find similar market reactions for insurance companies. We also observe a significantly stronger (positive) market reaction for non-advanced approaches banks than for advanced approaches banks around the Final Rule issue date. Furthermore, we find that market reactions are primarily associated with the magnitude of unrealized gains and losses on the AFS portfolio of banks. Our bootstrapping analysis suggests that this association is unique to our identified events. Collectively, these results give us confidence that the observed stock market reactions are driven by the AOCI filter removal and not by other confounding events.

8 Illiquid AFS securities usually include complex structured investments such as collateralized debt or loan obligations, non-agency mortgage-backed and other asset-backed securities.

9 Non-advanced approaches banks have to make the AOCI filter opt-out election when they file the Call Report or FR Y-9 report for the first reporting period after the date upon which they become subject to the final rule. The new capital regulations for non-advanced approaches banks are effective from January 1, 2015. 
Second, using quarterly data for U.S. banks in the period from 2009 to 2014, we find no evidence that advanced and non-advanced approaches banks decrease the maturity of their investment portfolio and the proportion of investment securities classified as AFS, in the Proposal or Final Rule periods relative to the benchmark group. Interestingly, advanced and non-advanced approaches banks significantly reduce the proportion of illiquid (Level 3 fair valued) assets in their AFS portfolio in the Proposal period, when both groups of banks would have been affected by the AOCI filter removal. However, in the Final Rule period the initial reduction of Level 3 AFS securities is partially reversed for the non-advanced approaches banks, when the AOCI filter removal was turned into an option for these banks. In contrast, advanced approaches banks experience a further decrease in illiquid investment securities in the Final Rule period. In additional analyses using hand-collected data for a subset of banks, we find that these trends are driven by real investment decisions related to changes in net purchases of Level 3 securities. Finally, we do not find a similar decrease in the proportion of Level 3 trading securities for advanced approaches banks, mitigating the concern that the risk reduction in their AFS portfolio is driven by other concurrent regulations affecting systematically important banks. Taken together, our results suggest that banks reduced their exposure to riskier illiquid assets in response to the expected removal of the AOCI filter.

We contribute to extant literature by providing empirical evidence on the merits of the extended use of fair values in regulatory accounting. Our analyses of stock market reactions suggest that investors perceive the extension of regulatory fair value accounting as increasing regulatory costs. To the extent that the observed market reactions are capturing the increased likelihood of (undue) regulatory intervention, shareholder losses might be indicative of potential social welfare costs. However, combined with the finding of reduced bank risk taking, our capital market results are also consistent with a reduction in the put option value 
provided by deposit insurance, and thus, wealth transfers from shareholders to depositors. Our tests cannot distinguish between these two non-mutually exclusive explanations. Specifically, changes in security prices primarily reflect the private costs and benefits of individual investors, but may not fully capture the social costs and benefits of this regulatory change.

Further, our findings inform the debate among regulators and researchers over whether capital adequacy calculations should be based on fair values (e.g., Dewatripont and Tirole, 1994; Allen and Carletti, 2008; Plantin et al., 2008). Extant empirical research has largely focused on the potentially detrimental ex post effects of fair value accounting on procyclicality and contagion (e.g., Khan, 2010; Bhat et al., 2011). A recent exception is Ellul et al. (2014), which shows that the use of fair values in statutory accounting reduces ex ante risk-taking incentives in insurance firms. However, the authors caution that their results might not be generalizable to the banking industry because of institutional aspects such as 'too big to fail'. We follow the call of Acharya and Ryan (2016) to explore the link between fair value accounting and risk-taking in the banking setting and complement Ellul et al. (2014) by showing that fair value-based capital requirements mitigate the ex ante risk-taking incentives of banks. Moreover, we document that banks change their risk-taking behavior even before the fair value requirements become effective.

Interestingly, our results differ from the findings of two prior studies examining the investment behavior of banks around a similar change in accounting. Beatty (1995) and Hodder et al. (2002) find evidence that banks change both the proportion of investment securities and the maturity of investment securities around the adoption of SFAS $115{ }^{10}$ However, because SFAS 115 affected all banks, the lack of a valid control group in these studies makes it difficult to control for potential time confounding effects. In our setting, we

10 SFAS 115 was introduced in 1994 and required previously disclosed unrealized fair value gains and losses on AFS securities to be recognized in accounting equity. 
can exploit the fact that some firms are completely unaffected by the AOCI provision or can opt out, which allows us to examine the effects of alternative regulatory accounting regimes on banks' investment behavior.

The paper proceeds as follows. Section 2 delineates the accounting and the regulatory treatment of unrealized fair value gains and losses on AFS securities and describes the events leading up to the passage of the Final Rule. Section 3 discusses the implications of the removal of the AOCI filter and develops the hypotheses. Section 4 describes our sample. Section 5 details our empirical approach and provides our main empirical findings. Section 6 discusses some limitations of our analyses and concludes.

\section{Background}

\subsection{Accounting for investment securities}

Before FASB Staff Position (FSP) FAS 115-2 and FAS 124-2

Banks hold a significant amount of investment securities primarily for the purposes of interest rate risk and liquidity management (e.g., Beatty, 1995). ${ }^{11}$ Under Statement of Financial Accounting Standards (SFAS) 115, investment securities that are not held for trading can be classified as held-to-maturity (HTM) or available for sale (AFS). Debt securities may only be classified as HTM if the bank has the positive intent and ability to hold those securities until maturity. HTM securities are recognized at amortized cost with fair values only disclosed in the footnotes. A feature of this category is that sales of HTM securities before maturity are restricted to certain circumstances. ${ }^{12}$ Any sales that do not fall into the "rare event" category would call into question ("taint") the classification as HTM and

11 Investment securities generally comprise highly liquid marketable securities such as instruments issued by the U.S. government and its agencies, but also mortgage-backed securities and, to some extent, equity securities.

12 For example, when there is a significant deterioration of the issuer's creditworthiness or changes in regulations that significantly affect the banks' original intent or ability to hold these securities until maturity. 
could necessitate the transfer of all HTM securities to AFS. The restrictive nature of the HTM category is probably the reason why banks classify only a small proportion of investment securities as HTM. ${ }^{13}$ AFS securities are measured at fair value with any unrealized fair value gains and losses directly recognized in equity as part of the other comprehensive income (OCI). Unrealized fair value losses on HTM and AFS securities only affect income if they are considered other-than-temporary, meaning that there is significant doubt that the firm has the intent or ability to hold the security until the recovery of its amortized cost basis.

\section{After FASB Staff Position (FSP) FAS 115-2 and FAS 124-2}

During the recent Financial Crisis, bankers complained that SFAS 115 forced them to recognize excessive other-than-temporary impairments (OTTIs) that were triggered by illiquidity in the debt markets and not by a decline in expected cash flows. ${ }^{14}$ Pressured by Congress the FASB issued a FASB Staff Position (FSP) that amends the impairment related provision of SFAS 115 (Pulliam and McGinty, 2009). According to the FSP, only the credit loss portion of OTTIs has to be recognized in income, which refers to the difference between the amortized cost and the present value of expected cash flows that the firm does not expect to collect until the maturity of the security. OTTIs related to all other factors are recognized in OCI for both HTM and AFS securities (FSP FAS 115-2 and FAS 124-2). However, temporary fair value changes due to changes in liquidity, interest rates, or credit spreads must be recognized in OCI only for AFS securities. These amendments became effective in the second quarter of 2009.

13 Evans et al. (2014) report that HTM securities declined from 15.0 percent to 1.8 percent of total assets between 1994 and 2007.

14 Bankers' claims were somewhat misguided, since under previous SFAS 115 rules OTTIs could not be triggered due to illiquidity unless the bank could not hold the securities until the recovery of the amortized cost basis. Once triggered, however, the OTTI would be affected by any market illiquidity to the extent required by fair value measurement. 


\subsection{Regulatory treatment of fair value gains and losses on available-for-sale securities}

Bank regulators' main objective is to ensure financial stability and to protect the interests of depositors who lack the incentives to monitor banks. By imposing minimum capital requirements that are sensitive to the risk of banks' assets, regulators attempt to reduce banks' excessive risk taking. Specifically, capital regulations induce bank owners to raise capital when they invest in riskier assets (Kim and Santomero, 1988). Bank regulators use accounting equity to determine regulatory capital. However, to better serve the prudential role of regulatory capital, regulators apply so-called prudential filters to adjust accounting amounts. For example, they exclude goodwill and unrealized gains of fair valued liabilities that result from a deterioration of the banks’ own credit risk.

Similarly, under previous regulations fair value changes on AFS debt securities were excluded from the calculation of regulatory capital. Losses on AFS debt securities affected regulatory capital only when they were realized through impairment or sale. The original motivation behind this prudential treatment was to exclude (presumably temporary) unrealized fair value changes on AFS debt securities that were irrelevant for regulatory purposes if banks held the securities until maturity (Laux, 2012). Indeed, during the financial crisis this favorable regulatory treatment acted as a safeguard by shielding banks' regulatory capital from unrealized losses on AFS debt securities (Laux and Leuz, 2010; Badertscher et al., 2012).

However, while temporary price distortions due to illiquidity in markets might not be important if a bank can hold on to the assets, they can be very relevant when banks are likely to be forced to sell these assets (Laux, 2012). In addition, by not including fair value changes in regulatory capital, the regulator effectively treats AFS securities as if they were accounted 
at historical cost, where deterioration of underlying asset values does not lead to a transfer of control. As a result, the solvency constraint has less bite, which creates strong incentives for asset substitution ( $\mathrm{Lu}$ et al., 2012). Moreover, in economic downturns this regulatory treatment provides banks with incentives to retain illiquid troubled assets, rather than to sell them early (e.g., Diamond and Rajan, 2011). Hence, while ex post prudential filters might dampen the impact of fair value losses on regulatory capital, ex ante they provide adverse incentives for excessive risk taking at the expense of deposit insurance funds and ultimately taxpayers. Regulators have recognized this problem, and new regulations require the inclusion of unrealized gains and losses on AFS debt securities in regulatory capital, as outlined in the next section (BCBS, 2011; Final Rule, 2013).

\subsection{Events leading up to the removal of the AOCI filter}

The pertinent events leading to the publication of the Final Rule are shown in Table 1. In Table 1 we classify these events based on whether they increase or decrease the likelihood that the removal of the AOCI filter will be implemented in the Final Rule. On December 16, 2010, the Basel Committee issued details of the Basel III regulatory framework, which was hailed as "a landmark achievement that will help protect financial stability and promote sustainable economic growth" (BCBS, 2010). A main objective of Basel III is "to raise both the quantity and the quality of the regulatory capital base” (BCBS, 2010, paragraphs 7-9). Paragraph 52 of Basel III lists what banks must include in common equity Tier I capital. ${ }^{15}$ One of these items is AOCI, which primarily comprises unrealized gains and losses on AFS

15 Basel III breaks Tier 1 capital into Common Equity Tier 1 capital and Additional Tier 1 capital. The former is considered the highest quality capital and banks are required to maintain a Common Equity Tier 1 capital of at least $4.5 \%$. Total Tier 1 capital is required to be above $6 \%$. 
securities. ${ }^{16}$ The final Basel III regulatory framework, which maintained the provision regarding the inclusion of AOCI, was issued on June 1, 2011 (BCBS, 2011). Several organizations expressed concerns about the potential detrimental effect of this provision amid fears that it would be incorporated into U.S. rules implementing the Basel III framework (e.g., The Clearing House, 2011). We analyze the capital market reactions to these two events because investors likely had similar concerns around these dates.

Indeed, on June 7, 2012 the Federal Reserve published three notices of proposed rulemaking (NPR) ${ }^{17}$, which proposed the removal of the AOCI filter for all banks subject to the Basel III regulatory framework, and it invited interested parties to submit comments by September 7, 2012. Just a month after publication, however, the comment period was extended to October 22, 2012 "to allow interested persons more time to understand, evaluate, and prepare comments” on the Proposal (Federal Reserve, 2012). A news article by SNL Financial (Event no. 5) attributes the decision to extend the comment period to the sheer number of comment letters received by regulators. In particular, the article mentions the comment letter submitted by ISDA in which they note that "the AOCI provision would bring the unintended consequences of increased volatility and pro-cyclicality into capital requirements” (Stovall, 2012). Such concern was shared by Thomas Curry, Comptroller of the Currency at an American Bankers Association (ABA) convention, who promised to carefully evaluate the impact that the AOCI filter removal would have on community banks (Event no. $6)$.

16 Unrealized gains and losses on cash flow hedges are also included in AOCI, but they continue to be excluded from the calculation of regulatory capital.

17 The three NPRs were: 1) Regulatory Capital Rules: Regulatory Capital, Implementation of Basel III, Minimum Regulatory Capital Ratios, Capital Adequacy, and Transition Provisions; 2) Regulatory Capital Rules: Standardized Approach for Risk-weighted Assets; Market Discipline and Disclosure Requirements; and 3) Regulatory Capital Rules: advanced Approaches Risk-based Capital Rule; Market Risk Capital Rule. 
Concerns about the possible impact of the implementation of the published NPRs ${ }^{18}$ led the Federal Reserve, FDIC, and the OCC to issue a joint press release in which they advised interested parties that the NPRs would not be implemented by the previously published effective date of January 1, 2013 (Event no. 7). Notwithstanding the end of the NPR comment period and the delay in the issue of the Final Rule implementing the NPRs, many industry representatives continued to lobby against the AOCI filter removal. ${ }^{19}$ In February 2013, Federal Reserve Governor Daniel Tarullo was summoned to a U.S. Senate Committee on Banking, Housing, and Urban Affairs meeting to update the Committee on Wall Street reforms and consumer protections. During the hearing, Tarullo explained that the Federal Reserve received over 2,000 comment letters on the NPRs, most of which focused on the extent to which provisions such as the removal of the AOCI filter would be burdensome for small and community banks (Event no. 10). ${ }^{20}$

The Federal Reserve issued the Final Rule (Federal Reserve, 2013), which removes the AOCI filter for advanced approaches banks and gives a one-time option to non-advanced approaches banks to opt-in or out of the AOCI filter, on July 2, 2013 (Event no. 12).

$$
<<\text { Insert Table } 1 \text { around here }>>
$$

In Table 1, each news event is indicated as either increasing or decreasing the likelihood of the AOCI filter removal. News events reporting opposition to or delays in the implementation of the proposed rule are deemed to decrease the likelihood of AOCI filter

18 In particular, the concern related to the proposal to remove the AOCI filter.

19 These included Independent Community Bankers of America (Events no. 8 and no. 11) and insurer-owned banks (Event no. 9).

20 The dates attributed to Event no. 6 and Event no. 10 pertain to news articles summarizing events that took place prior to the date of these articles. Even though we were not able to identify news about these events prior to the dates of these news articles, we re-run all the analyses documented in the study after dropping Event no. 6 and Event no. 10 to ensure that our results are not driven by possible news event date misspecification. Untabulated results for this specification yield similar inferences to those documented in the study. 
removal. Conversely, events that indicate progress in the implementation of the Basel III requirements are deemed to increase the likelihood of AOCI filter removal.

\section{Hypotheses Development}

\subsection{Capital market reactions}

We start by examining the stock market reactions to news events leading up to the announcement of the Final Rule. As mentioned above, market reactions to these news events depend on the likelihood that the rule would be implemented and the trade-off between the perceived benefits of greater regulatory discipline in bank risk taking and the associated costs of the potentially higher likelihood of regulatory intervention. The first-order effect of the AOCI filter removal lies in the recognition of accumulated unrealized fair value gains and losses at the adoption date of the regulation. While this one-time effect likely was incorporated into market participants' and bank managements' expectations, we argue that the effects of the AOCI filter removal on the future volatility of fair values and regulatory capital

are more important. ${ }^{21}$ Supporting this conjecture, all news articles and bank comment letters addressing the AOCI filter removal indicate that the primary concern is the increased volatility and not the one-time effect on regulatory capital.

Since the bulk of the AFS portfolio consists of liquid, high quality, interest rate sensitive investment securities, changes in interest rates are the primary source of volatility in the fair values of these securities. This incremental volatility should increase the likelihood of regulatory intervention in good times, when rising interest rates result in unrealized fair value losses on AFS securities that are not offset by unrealized gains on economically matched deposit liabilities. To reduce volatility from changes in interest rates, banks could shorten the maturity of their investments, reclassify AFS securities to HTM, or change the nature of their

21 See Beatty et al. (1996) for a similar argument. 
hedging activities. ${ }^{22}$ Both the anticipated increase in the volatility of regulatory capital and real actions to mitigate this volatility would impose costs on banks and, in turn, negatively affect firm value.

Banks also hold illiquid AFS securities that expose them to procyclical changes in credit spreads that can significantly impact regulatory capital, especially during downturns, as evidenced during the recent Financial Crisis. To reduce this source of volatility, bank managers might be induced to limit their exposure to credit risk in their AFS portfolios. To the extent that investors expect the removal of the AOCI filter to limit excessive risk-taking, we expect to observe positive market reactions. However, because of their limited liability and the put option value provided by deposit insurance, investors might benefit from banks' risk taking. In this case, we would expect negative market reactions.

Overall, ex ante it is difficult to determine the sign and the magnitude of the net benefits of the regulatory change from the investors' perspective. Two recent studies find that relaxation of fair value accounting rules, and thus of regulatory constraints, led to positive stock market reactions during the financial crisis (Bischof et al., 2014; Bowen and Khan, 2014). This evidence suggests that investors might perceive the costs associated with regulatory intervention to outweigh the benefits of greater regulatory discipline. To the extent that the regulatory cost hypothesis holds, we expect market participants to negatively (positively) view events that increase (decrease) the likelihood of AOCI filter removal. Thus, our first hypothesis is as follows:

H1: There is a negative (positive) market reaction to events that increase (decrease) the likelihood of AOCI filter removal.

22 Banks could use other hedging instruments such as interest rate swaps, collars, and floors because changes in the value of cash-flow hedges are still filtered out of the AOCI under the Final Rule. However, these instruments are more expensive to implement, potentially less predictable as a hedge, and would require clearing. Moreover, only very large banks would have access to such derivative markets. 


\subsection{Changes in investment behavior}

Capital market reactions at least partly reflect market participants' expectation of changes in banks' investment behavior in anticipation of the higher probability of regulatory intervention under fair value-based capital requirements. Two earlier studies provide evidence that banks altered their investment strategy in response to the (potential) impact of partial fair value accounting on the volatility of accounting equity, as a result of SFAS 115 adoption. Beatty (1995) examines the change in investment behavior of bank holding companies that early adopted SFAS 115 versus that of regular adopters. The study finds a decrease in both the proportion of assets held in investment securities and the maturity of investment securities held by early adopters. Beatty (1995) attributes this finding to the early adopters' expectation that regulatory capital would be affected. Ultimately, regulators decided not to include unrealized fair value gains and losses on AFS securities in Tier 1 capital. Following this decision, Hodder et al. (2002) find that banks altered initial portfolio allocations made in the period examined by Beatty (1995) to undo their initial over- or under-classification of AFS securities. While these studies provide useful insights into the potential effects of fair value accounting on investment behavior, the lack of a valid control group prevents these studies from controlling for potential time confounding events.

Based on the above prior literature and bankers' arguments, we expect that banks would classify less investment securities into the AFS category in response to the AOCI filter removal. Therefore, we formulate the following hypothesis:

\section{H2: Banks reduce the amount of investment securities classified in the AFS category in response to the removal of the AOCI filter.}

Notwithstanding this, the limited ability to sell securities classified in the HTM category combined with the Basel III requirement that banks must hold a certain level of high quality 
liquid assets might provide disincentives to reduce the relative proportion of investment securities in the AFS category. Alternatively, banks might shorten the maturity of their investment securities to reduce the sensitivity of regulatory capital to interest rate changes. Hence, we formulate the next hypothesis as follows:

\section{H3: Banks shorten the maturity of the investment portfolio in response to the removal of the AOCI filter.}

Finally, we examine whether banks reduce the proportion of risky assets in the AFS portfolio. As mentioned above, theoretical studies suggest that under a fair value-based regulatory regime, banks have reduced risk-shifting incentives as compared to a historical cost system (Dewatripont and Tirole, 1994; Lu et al., 2012). Specifically, anticipating that ex post realizations of risk are more likely to lead to a transfer of control to the regulator, when regulatory capital is based on fair values, managers have lower ex ante risk-taking incentives. We test this prediction by analyzing whether banks reduce the proportion of illiquid Level 3 AFS assets in response to the AOCI filter removal. We examine illiquid securities, comprising primarily structured financial products such as collateralized debt obligations and non-agency mortgage backed securities, because they represent the riskiest investments in the AFS portfolio. The fair values of these investments are volatile and often carry unrealized losses that have not been considered in the calculation of regulatory capital under previous regulations. Thus, the removal of the AOCI filter likely provides incentives for banks to reduce the proportion of illiquid assets, because it would force banks to recognize future volatility in regulatory capital. Hence, we formulate our final hypothesis as follows:

\section{H4: Banks decrease the proportion of illiquid investment securities held in the AFS portfolio in response to the removal of the AOCI filter.}




\section{Sample Selection}

For our event study analysis, the sample period extends from the second quarter of 2010 to the third quarter of 2013 during which the previously discussed events occurred. We identify 1,088 U.S. banks on SNL Financial. We drop banks for which Tier 1 capital data is not available throughout the whole sample period (371 banks), market data is not available on $\mathrm{CRSP}^{23}$ (402 banks), and banks with average total assets less than $\$ 500$ million, for which Basel III does not apply (50 banks). Thus, our final sample for this analysis consists of 265 banks. We supplement our sample with 82 insurance companies through SNL Financial for which market data on CRSP is available. Due to missing data required to calculate the variables used in the cross-sectional analysis, our sample drops to 232 banks for this analysis.

The sample period for our investment analysis extends from the first quarter of 2009, one quarter before FSP FAS $115-2$ and $124-2$ became effective, to the third quarter of 2014, three quarters after the implementation date of the Final Rule for advanced approaches banks, January 1st, $2014 .^{24}$ For this analysis, we use the same sample of firms used in the crosssectional analysis (232 banks) and add 27 small banks (total assets less than \$500 million), for which Basel III regulations do not apply, yielding a total sample of 259 banks.

\section{Empirical Analysis}

\subsection{Capital market reactions}

\subsubsection{Overall capital market reactions}

To study the overall market reaction to the news about the AOCI filter removal, we examine three-day windows around the events identified in Table 1 . These windows cover the period from one day before to one day after the news reaches the market. Moreover, to

\footnotetext{
23 The majority of these banks are traded on the OTC market.

24 For non-advanced approaches banks the implementation date is January 1, 2015.
} 
disentangle market reaction to news about the AOCI filter removal from confounding news and other macro effects, we augment our sample with 82 insurance firms. Since the AOCI filter removal applies only to banks, we do not expect significant market reactions (in the predicted direction) to related news for insurance firms. Similar to Beatty et al. (1996), we estimate the following regression model:

$$
\text { Ret }_{i t}=\alpha_{i}+\beta_{i} \text { Market_Rtn }_{t}+\gamma_{i} 5 Y R_{-} \text {Bond }_{-} \text {Rtn }{ }_{t}+\delta_{i} \text { Signed }_{-} \text {Events }_{t}+\varepsilon_{i t} \text { (Eq. 1) }
$$

where Ret $_{i t}$ refers to daily returns including dividends for bank $i$ and time $t$, Market_Rtn ${ }_{t}$ refers to the CRSP value weighted market return, and $5 Y R \_B o n d \_R t n_{t}$ refers to the return on a 5 Year Treasury Bill. Signed_Events is an indicator variable that takes the value of $+1(-1)$ for events that indicate a decrease (increase) in the likelihood of AOCI filter removal, and 0 otherwise. Table 2 provides details of the sample distribution and descriptive statistics of the variables used in this analysis.

$<<$ Insert Table 2 around here $>>$

In line with our first hypothesis the results presented in Panel A of Table 3 indicate a significantly positive coefficient on Signed_Events (at the 1\% level) for banks, but not for insurance companies. Importantly, the Signed_Events coefficient for banks is significantly different from that of insurance companies at the $5 \%$ level, mitigating the concern that the result for banks is due to confounding news affecting the financial industry. To increase the power of our analysis and to mitigate potential event date misspecification, we also conduct a test where we consider only a subgroup of regulatory events that are presumably more important to banks. Specifically, we replace Signed_Events in Eq. 1 with Signed_Reg, which is an indicator variable that takes the value of $+1(-1)$ for events related to announcements of the Bank for International Settlements and the Federal Reserve (i.e., Events 1, 2, 3, 4, 7 and 
12). Again, we find a significantly positive coefficient on Signed_Reg (at the 1\% level) for banks but not for insurance companies. The difference in coefficients on Signed_Reg between banks and insurance companies is statistically significant at the $1 \%$ level. Taken together, the results suggest that market participants positively (negatively) viewed news that decreased (increased) the likelihood of AOCI filter removal. Hence, investors perceive the costs associated with the regulatory change to exceed possible benefits from improved regulatory discipline.

$<<$ Insert Table 3 about here $>>$

The previous analysis indicates that, on average, there was a positive market reaction to news events that decreased the likelihood of AOCI filter removal. Nonetheless, as different events may differ in their market relevance, we next include an indicator variable for each individual event in the regression:

$$
\operatorname{Ret}_{\mathrm{it}}=\alpha_{i}+\beta_{i} \text { Market_Rtn }{ }_{t}+\gamma_{i} 5 Y R_{-} \text {Bond }_{-} \text {Rtn }_{t}+\sum_{k=1}^{K} \delta_{i k} \text { Events }_{k t}+\varepsilon_{i t}
$$

where $\delta_{i k}$ measures the effect of event $k(k=1,2,3, \ldots K)$ on bank $i$ and $K$ is the total number of events, i.e., 12.

Table 4 indicates that four of the events elicited a market reaction for banks that was significantly different (at the $1 \%$ level) from insurance companies in the predicted direction. ${ }^{25}$ We find significant negative abnormal returns for Event_2 and Event_4, and significant positive market reactions for Event_10 and Event_12. Event_2 relates to the publication of the revised Basel III regulations by the Bank of International Settlements that confirmed the AOCI filter removal. Event_4 relates to the announcement that the Federal Reserve Board

25 Insurance companies experience significant returns with the signs predicted for banks for only two of the 12 events. 
extended the comment period on the three proposed capital rules until October 22, 2012. On Event_10, the Federal Reserve Governor Daniel Tarullo admitted in his testimony in front of the U.S. Senate Committee on Banking, Housing, and Urban Affairs that banking agencies were aware of the strong opposition to the proposed rules, particularly to the removal of the AOCI filter. Finally, Event_12 relates to the publication of the Final Rule, which provided the opt-out option from the AOCI filter removal for non-advanced approaches banks.

To control for other bank-specific confounding events, we perform an additional test, in which we compare advanced approaches banks to non-advanced approaches banks. In particular, if our interpretation of the market reaction for Event_12 is correct, we should observe a positive market reaction for non-advanced approaches banks and a negative or no market reaction for advanced approaches banks. In line with this expectation, in untabulated results we find that while the market reaction for this event for non-advanced approaches banks is positive (coefficient $=0.0054$ ) and significant at the $1 \%$ level, the market reaction for advanced approaches banks is insignificantly different from zero. Moreover, the difference in these market reactions is significant at the $5 \%$ level.

In interpreting the economic significance of the results reported in Tables 3 and 4 , it is important to note that the individual event returns reflect the average return during the event window. To calculate the overall sample abnormal return for each event one needs to multiply the reported coefficients by the length of the event window (three days). Similarly, the coefficient on Signed_Events reflects the average abnormal return over a 36-day event period (i.e., 12 events with a three-day event window). Thus, the overall sample abnormal return is around 5\% (=0.0014*36). The Signed_Reg event results reflect the average over an 18-day event period resulting in an overall sample abnormal return on regulatory events of around $3.4 \%(=0.0019 * 18)$. 


\subsubsection{Cross-sectional analysis of abnormal returns}

To mitigate the concern that average market reactions are driven by other aspects of the Final Rule rather than the AOCI filter removal, we examine whether market reactions vary cross-sectionally with AFS portfolio characteristics. First, we expect that the impact of the rule change will increase with the size of the AFS portfolio. We measure AFS as the amortized cost of AFS securities divided by total assets averaged over the sample period. ${ }^{26}$ Second, we predict that the expected effects of the rule change will depend on the interest rate sensitivity of AFS securities, which increases with their duration. Following Beatty et al. (1996), we proxy for duration using Maturity measured as total debt securities maturing in three years or more divided by the total value of debt securities averaged over the sample period. ${ }^{27}$ In addition, we include a variable capturing the sensitivity of the firm's equity value to changes in interest rates. Exposure is the coefficient on the change in U.S. Federal Funds Rate in a regression of bank stock returns on market return and change in U.S. Federal Funds Rate. ${ }^{28}$ To capture the one-time effect of the rule change on the level of regulatory capital, we use $U R G L$, which is calculated as the amount of unrealized fair value gains and losses on securities recognized in equity divided by total assets averaged over the sample period. Since URGL is primarily determined by changes in interest rates, this variable also serves as a proxy for the interest rate sensitivity of banks' AFS portfolios. We expect a positive association between Maturity, Exposure, URGL, and the magnitude of abnormal returns.

26 In this analysis the sample period extends from the second quarter of 2010 and ends in the third quarter of 2013.

27 We recognize that Maturity is a crude measure of the interest rate sensitivity of floating rate securities. However, data on banks' relative amounts of fixed versus floating rate securities split by maturity is not available.

28 The market return used is the daily CRSP value-weighted return including dividends, while the change in U.S. Federal Funds Rate is calculated as $\frac{\text { U.S.Federal Funds Rate }}{t-\text { U.S.Federal Funds Rate }_{t-1}}$. 
We also control for illiquidity risk in the bank's AFS portfolio by including Level3AFS measured as the dollar value of Level 3 AFS securities scaled by the amortized cost of AFS securities. Ex-ante the direction of the association between Level3AFS and the magnitude of abnormal returns is unclear, since bank risk taking might create as well as destroy value for shareholders.

Given that increased capital volatility is likely to be more problematic for banks with relatively low levels of regulatory capital, we include Tier1 in our model, which is computed as Tier 1 capital scaled by total assets calculated over the sample period. A negative association with the magnitude of abnormal returns is expected. We also include volatility of Tier 1 capital, Vola_Tier1, computed as the standard deviation of Tier 1 over the sample period scaled by the mean Tier 1 capital. Banks with a greater volatility of Tier 1 capital before the rule change are expected to be affected more by the inclusion of AOCI in regulatory capital. We also control for Debt, measured as non-deposit liabilities divided by total assets, and Size, measured as the logarithm of total assets, to allow stock returns to vary by bank size. We do not make predictions about the relationship of these variables with abnormal returns. Table 5 provides descriptive statistics of the variables of interest for the 232 banks in our sample.

$<<$ Insert Table 5 around here $>>$

To examine the cross-sectional determinants of event period reactions, we undertake two separate analyses. The first analysis involves a two-stage procedure. In the first stage, we run Eq. 1 for each individual bank, and in the second stage we regress the bank-specific coefficient on variable Signed_Events $(\delta)$ on the cross-sectional determinants in Eq. 3: 


$$
\begin{aligned}
\delta_{\mathrm{i}}= & \alpha_{0}+\beta_{1} \text { AFS }_{i}+\beta_{2} \text { Maturity }_{i}+\beta_{3} \text { Exposure }_{i}+\beta_{4} \text { URGL }_{i}+\beta_{5} \text { Level }_{\text {AFS }}+ \\
& \beta_{6} \text { Tier }_{i}+\beta_{7} \text { Vola_Tier }_{i}+\beta_{8} \text { Debt }_{i}+\beta_{9} \text { Size }_{i}+\varepsilon_{i}
\end{aligned}
$$

The second analysis is based on the Sefcik and Thompson (1986) methodology, which gives similar coefficients to the two-stage procedure in the first analysis but adjusts standard errors for heteroskedasticity and residual cross-correlation that arises when events impact all sampled firms at the same time. Specifically, we create 10 weighted portfolio returns, one for each firm characteristic studied and the intercept, which are then used as the dependent variables in Eq. 1. To create the weighted portfolio of returns we create two matrices: Martix $\mathrm{R}$ is a $t \times \mathrm{x}$ matrix, where $t$ is the number of time periods in our sample period (i.e., 881 trading days) and $j$ the number of firms (i.e., 232 banks), and Matrix $\mathrm{F}$ is a $j \mathrm{x} k$ matrix, where $k$ consists of the different firm characteristics plus the intercept. Finally, the weighted portfolio of returns is calculated as $\left(\mathrm{F}^{\prime} \mathrm{F}\right)^{-1} \mathrm{~F}^{\prime} \mathrm{R}^{\prime}$.

The results of the cross-sectional analysis are reported in Table 6. In Panel A, URGL and Tier 1 show the predicted signs and are statistically significant at the $1 \%$ and $5 \%$ level, respectively, suggesting that market reactions are stronger for banks with larger net unrealized gains and lower Tier 1 capital. When we use the Sefcik and Thompson (1986) methodology, only the coefficient on URGL remains significant (Table 6 Panel B). Hence, banks with the largest amount of net unrealized gains are expected to be affected most by the inclusion of AOCI items in regulatory capital. Specifically, these banks are the ones that benefited most from the low interest rate environment in past years and are likely to be worse off in a period of increasing interest rates. ${ }^{29}$ Importantly, these results buttress the notion that concerns over

29 Indeed, in unreported descriptive analyses we find that sample banks that were in the top quartile in terms of unrealized gains in the Q3 2012, when interest rates were low, experienced the largest unrealized losses in 2013, when interest rates started to increase. 
the removal of the AOCI filter are the primary driver of the market reactions observed in the previous section.

Our previous analyses are based on the premise that the AOCI effects captured by net unrealized gains (URGL) are orthogonal to any other changes in banking regulations and that absent the AOCI filter removal daily stock returns are unrelated to URGL (and the other cross-sectional variables). However, it is possible that our findings are the result of test misspecification or some omitted variable correlated with net unrealized gains (e.g., Larcker et al., 2011). For example, the positive correlation between net unrealized gains and stock returns might be due to a general trend stemming from the gradual recovery of market values of AFS securities during our sample period. In this case we would expect net unrealized gains to be related to returns even on non-event days.

To address this concern, we perform a bootstrapping analysis where 12 three-day nonevent time windows were randomly selected. In randomly selecting these 12 three-day nonevent windows we mimic the year-by-year distribution and the signs of our events from Q2 2010 to Q3 2013. That is, we select one, one, seven, and three non-event windows in 2010, 2011, 2012, and 2013, respectively, and we sign them according to the pattern displayed in Table 1. Using these 12 non-event windows, we run Eq. (1) for each bank in our sample. Then, we use the bank-specific coefficients on the Signed_Events variable in Eq. (1) as the dependent variables for the cross-sectional model, Eq. (3). We repeat this procedure 1,000 times to obtain the empirical distribution of one thousand non-event coefficients for each variable. Similar to Larcker et al. (2011), we test whether the coefficients for our event days (reported in Table 6 Panel A) are significantly different from the average of one thousand estimated coefficients for the non-event days. This approach allows us to rule out that the 
observed relationship between net unrealized gains and abnormal returns is a general phenomenon and not related to the removal of the AOCI filter.

Table 6 Panel C shows the results of our bootstrapping analysis. For each independent variable used in the cross-sectional analysis we tabulate the coefficients from the event date regression $(\beta)$ as shown in Table 6 Panel $\mathrm{A}$ and the average coefficients resulting from repeating the same regression 1,000 times on non-event dates $(E(\beta))$. We conduct $t$-tests for the differences between $\beta$ and $E(\beta)$ using the empirical distribution of $\beta$ s on non-event days to compute the standard error of $E(\beta)$. We find that these differences are significant at the $1 \%$ level. ${ }^{30}$ In particular, the average coefficient on URGL on non-event days (0.027) is significantly smaller than the coefficient for our events (0.294). This result suggests that the observed variation in returns is unique to our event days and, therefore, is likely to be driven by the AOCI filter removal rather than the result of test misspecification or omitted correlated variables.

$<<$ Insert Table 6 around here $>>$

\subsection{Changes in investment behavior}

In this section we study whether banks adjust their investment strategy in response to the new regulations. Figure 1 highlights the specific features of our empirical strategy to isolate the effects of the AOCI filter removal on banks' investment behavior. We divide the sample period into three separate time periods. The Pre-Proposal period extends from Q1 2009 to Q2 2012, when the Proposal was issued (June 2012). The Proposal period begins in Q2 2012 and

30 The significantly larger t-statistics in the bootstrapping analysis are due to the generally small standard deviation of $E(\beta)$ s and the higher degrees of freedom that result in much smaller standard errors of the $E(\beta) \mathrm{s}$ than the standard errors of the $\beta$ s in Table 6, Panels A and B. 
ends in Q2 2013, just before the Final Rule was announced (July 2013). ${ }^{31}$ The Final Rule period starts in Q3 2013 and ends in Q3 2014. Further, we include three groups of banks that are differently affected by this regulatory change. Specifically, in addition to advanced approaches and non-advanced approaches banks, we supplement our sample of 232 banks with 27 small banks (total assets less than $\$ 500$ million) that are not subject to the new U.S. Basel III regulation (hereafter referred to as "Non-Basel” banks). Since the Proposal suggested the AOCI filter removal for all banks subject to Basel III rules, we can examine whether the Proposal affected their investment behavior relative to the unaffected Non-Basel banks. Second, because the Final Rule limited the mandatory removal of the AOCI filter to advanced approaches banks, we can benchmark their behavior against that of non-advanced approaches and Non-Basel banks in the Final Rule period. Thus, our setting provides us with an opportunity to identify the impact of particular amendments to prudential regulation on real economic decisions at different points in time. Specifically, we implement the following differences-in-differences regression:

Investment $_{\mathrm{it}}=\alpha_{0}+\beta_{1}$ Proposal $*$ NonAdvApproach $+\beta_{2}$ Final_Rule*NonAdvApproach + $+\beta_{3}$ Proposal $*$ AdvApproach $+\beta_{4}$ Final_Rule*AdvApproach + Controls + Firm Fixed effects + + Quarter - year Fixed effects $+\varepsilon_{i t}$

where Investment refers to the investment policy variables described below. Proposal takes a value of 1 for observations in the period between the issuance of the Proposal and the publication of the Final Rule, and 0 otherwise. Final_Rule takes a value of 1 for observations after the Final Rule was issued, and 0 otherwise. NonAdvApproach (AdvApproach) takes the value of 1 for non-advanced approaches (advanced approaches) banks, and 0 otherwise. The

31 Unlike market participants who immediately react to any changes in expectations, bank managers decide to make costly changes in their investment behavior only when there is a reasonably large probability of the regulatory change being implemented (Gulen and Ion, 2015). We take the announcement of the Proposal as the first strong signal of a pending regulatory change that is likely to have led to changes in investment behavior. 
interaction terms capture the incremental impact of the Proposal and Final Rule on the investment behavior of non-advanced approaches (NonAdvApproach) and advanced approaches banks (AdvApproach), respectively, relative to Non-Basel banks. We include quarterly unrealized gains and losses $U R G L$, Size, Tier 1 ratio (Tier1), and Debt as control variables. In addition, we control for return on assets $(R O A)$ and deposits scaled by total assets (Deposits). We include quarter-year fixed effects and firm fixed effects to control for unobserved firm heterogeneity in investment behavior. The differences-in-differences design and the inclusion of quarter-year fixed effects allow us to control for common trends in investment behavior of banks that are unrelated to the AOCI filter removal such as changes in market liquidity. Finally, we cluster standard errors at the bank level.

We construct the following investment policy variables. First, to measure the maturity of investment securities we follow Beatty (1995) and calculate the weighted maturity of the investment portfolio Weighted_Sec as ((Debt Securities with maturity 3-5 years/total securities)*3 + (Debt Securities with maturity 5-15 years/total securities)*5 + (Debt Securities with maturity $>15$ years/total securities)*15). The weightings are based on the arbitrary assumption that the average maturity in a given maturity bucket is 3 , 5, and 15 years, respectively. ${ }^{32}$ Ideally, we would use the specific maturity of AFS securities, but we do not have such data. However, because debt securities are primarily classified in AFS, this is unlikely to significantly affect our results. To capture changes in the proportion of investment securities that are classified as AFS, we construct AFS_Sec as the amortized cost value of AFS securities divided by the amortized cost of total investment securities, where total investment securities is the sum of AFS and HTM securities. Finally, to measure the proportion of illiquid assets in banks' AFS portfolios, we calculate Level3AFS as the amount

32 Our results are not sensitive to variations of these weightings. Also, we ran our analysis using total debt securities with maturities longer than 3 years scaled by total securities as an alternative maturity measure, and we obtain similar results. 
of Level 3 fair valued assets, i.e., those that are measured at fair value using unobservable inputs, divided by the amortized cost value of all AFS securities.

$<<$ Insert Table 7 around here $>>$

Table 7 shows descriptive statistics for the variables of interest for our pooled sample of Non-Basel, NonAdvApproach, and AdvApproach banks for the three sub-periods separately. The mean relative proportion of AFS securities (AFS_Sec) decreased from 91.2\% in the PreProposal period to $89.2 \%$ in the Proposal period, and further down to $85.3 \%$ following the publication of the Final Rule. While changes in the median AFS_Sec are miniscule, the more significant drop in the $25^{\text {th }}$ percentile values suggest that some banks decreased the proportion of their investment securities classified as AFS, i.e., classified more securities into HTM, both in the Proposal and in the Final Rule periods. However, it is evident from these figures that the significance of the HTM category is minor for most banks. The mean weighted maturity of securities (Weighted_Sec) increased from 1.75 years in the period before the Proposal date to 1.96 years in the period after the issuance of the Final Rule, indicating that banks were generally increasing the maturity of investment securities. The proportion of AFS Level 3 assets (Level3_AFS) decreased, on average, from 2.9\% to $2.1 \%$ in the Proposal period and $2.0 \%$ in the Final Rule period. Consistent with the interest rate sensitivity of AFS investments, unrealized gains and losses (URGL) increase slightly from the Pre-Proposal to the Proposal period, when interest rates decrease, and then they drop to become negative in the Final Rule period, when interest rates start to increase.

Table 8 presents the results for the analysis of banks' investment behavior. Results in Table 8 do not suggest that banks that would have been affected by the removal of the AOCI filter reduce the maturity of investment securities in the Proposal or the Final Rule periods. Regarding the classification of investment securities (AFS_Sec), we observe negative 
coefficients on the interaction terms only for advanced approaches banks (rows 3 and 4), but both are statistically insignificant. Overall, these results do not support bankers’ concerns.

Finally, we turn to the test of hypothesis H4. The results in column (3) of Table 8 suggest that both advanced and non-advanced approaches banks significantly reduced the proportion of illiquid securities in their AFS portfolio (Level3AFS) by 3.5\% and 1.6\%, respectively, in the Proposal period relative to Non-Basel banks (rows 1 and 3). ${ }^{33}$ However, in the Final Rule period, while advanced approaches banks appear to further decrease their illiquid AFS investments (row 4), the interaction term for non-advanced approaches banks is insignificant (row 2). This result suggests that non-advanced approaches banks have partially offset the initial reduction of Level 3 AFS securities in the Proposal period after they learned that they would not be affected by the Final Rule. The Wald tests in rows (5) and (6) indicate that advanced approaches banks reduce more of their risky AFS investments than non-advanced approaches banks in both the Proposal and the Final Rule period. Taken together, these results are consistent with banks decreasing the riskiness of their investment portfolio in anticipation of the removal of the AOCI filter.

$<<$ Insert Table 8 around here $>>$

Given that a number of our advanced approaches banks are Global Systemically Important Banks, we are concerned that the reduction of illiquid securities might be caused by other concurrent factors that these banks face. However, if these other concurrent trends affecting advanced approaches banks are the main drivers of our findings, then we should also observe a more pronounced decrease in illiquid securities in other fair value accounting categories. To test this, we analyze the change in the size of Level 3 securities held in the

33 The decrease in Level3AFS represents about 54\% (67\%) of the sample period average for advanced (nonadvanced) approaches banks, which is $6.4 \%$ (2.4\%). 
trading portfolio of banks around the Proposal and Final rule dates. We rerun Eq. 4 using the proportion of Level 3 trading securities relative to total trading securities (Level3Trading) as the dependent variable. Because Non-Basel banks only rarely have trading assets, for this analysis we only benchmark AdvApproach against NonAdvApproach banks. Results in Table 9 show that AdvApproach banks do not exhibit a more significant reduction in Level 3 trading securities than NonAdvApproach banks. This finding supports our interpretation that the reduction of illiquid AFS securities of AdvApproach banks is driven by the removal of the AOCI filter rather than by other concurrent factors affecting these banks.

$<<$ Insert Table 9 around here $>>$

Further, to mitigate the concern that the results reported in Table 8 are merely driven by the return of market liquidity over the sample period, we examine whether banks actually change their real investment decisions involving illiquid AFS securities. To this end, we hand-collect data from banks' disclosures of Level 3 rollforwards that allow us to distinguish purchases and sales of Level 3 AFS securities from transfers of these securities to other levels. We limit our analysis to the eight advanced approaches banks that are affected by the mandatory AOCI filter removal under the Final Rule and the ten largest non-advanced approaches banks. By comparing only the largest banks we mitigate a potential concern in our main analysis associated with using smaller banks as control banks, as they are inherently different, which might undermine their effectiveness as a control group (Beatty and Liao, 2014). Also, the largest banks are more likely to have expected that they would be subjected to the AOCI filter removal under the Final Rule after the Proposal came out. The sample period for this analysis starts in the first quarter of 2011, because separate disclosures regarding purchases, sales, issuances, and settlements for Level 3 assets are available only from then, and ends in the third quarter of 2014. 
Figure 2, Panels A and B show the total amount of net purchases (i.e., the net amount of purchases and sales) of Level 3 AFS securities for advanced approaches and non-advanced approaches banks, respectively. Both subsamples appear to have gradually increased their Level 3 net investment in the Pre-Proposal period. For example, advanced approaches banks invested a total of approximately $\$ 19$ billion in illiquid securities in the third quarter of 2011, while non-advanced approaches banks' net investments amounted to almost $\$ 2$ billion in the first quarter of 2012. Following the issuance of the Proposal, both subsamples responded with a decrease in net purchases. Interestingly, after the announcement of the Final Rule, while advanced approaches banks further reduced their net purchases to less than \$1bn in Q3 2014, non-advanced approaches banks increased their net investment in Level 3 AFS securities. These trends are consistent with our primary findings reported in Table 8.

Table 10 Panel A reports descriptive statistics for net purchases and net transfers to other fair value levels scaled by the amortized cost of AFS securities. The changes in net purchases of Level 3 securities across the three periods for both subsamples are similar to those observed in Figure 2. However, the table highlights that while the initial reduction in Level 3 net investments of non-advanced approaches is driven by sales in the Proposal period, advanced approaches banks primarily responded with reductions in new purchases in both the Proposal and Final Rule periods. All banks, on average, seem to have transferred assets from Level 3 to other levels, suggesting that return of market liquidity might partially contribute to our primary results. Advanced approaches banks exhibit larger transfers out of Level 3 in the Pre-Proposal and Proposal periods, but non-advanced approaches banks catch up in the Final Rule period. In Table 10 Panel B we report regression results for net purchases and net transfers as dependent variables. ${ }^{34}$ Model (1) shows that both groups of banks decrease net

34 Because of the small sample size (and firm clusters), we do not include quarter-year effects and do not cluster standard errors by bank (Petersen, 2009). However, the inclusion of Proposal and Final Rule control for time- 
purchases of Level 3 securities in the Proposal period, but this result is not significant, which might be due to low statistical power. However, in the Final Rule period, advanced approaches banks significantly decreased net AFS Level 3 investments, while non-advanced approaches banks significantly increased their Level 3 net investments. Finally, model (2) does not suggest that net transfers out of Level 3 were significantly different across the three periods and bank groups. Overall, these results confirm our primary findings in Table 8 and support the conclusion that the removal of the AOCI filter influenced real managerial investment decisions.

$<<$ Insert Table 10 around here $>>$

\section{Conclusion}

In this paper we examine the consequences of the AOCI filter removal, which requires the inclusion of unrealized fair value gains and losses on AFS securities in regulatory capital. In line with the hypothesis that the inclusion of unrealized gains and losses will result in increased regulatory costs, we find negative (positive) stock market reactions to news indicating an increased (decreased) likelihood of the AOCI filter removal. Further analysis shows that these market reactions are mainly driven by the relative magnitude of unrealized fair value gains and losses on AFS securities.

We do not find evidence that banks affected by the AOCI filter removal (i.e., advanced approaches banks) reduce the maturity of their investment portfolio or the proportion of AFS securities relative to benchmark banks. In contrast, our results suggest that affected banks reduce their investment in risky, illiquid Level 3 investment securities more than unaffected banks. The latter finding is consistent with theoretical predictions that basing regulatory

period effects. In addition, we include the return on 10-year Treasury Bills (10YR_Bond_Rtn) as a control variable for changes in interest rates. Inferences are similar when we include quarter-year fixed effects. Finally, we do not include the control variable Weighted_Sec, because it further reduces sample size. 
capital on fair values mitigates ex ante risk-shifting incentives of bank managers (Dewatripont and Tirole, 1994; Lu et al., 2012) and, therefore, improves regulatory discipline. Notwithstanding this, our study cannot speak to the ex post efficiency of fair value-based capital requirements, so we leave this for future research.

In interpreting our findings, several caveats are in order. First, our analysis of stock market reactions does not (and is not intended to) capture all costs and benefits associated with the removal of the AOCI filter. As mentioned earlier, our results primarily reflect the private costs and benefits and any social costs and benefits internalized by bank shareholders. Second, while our research design for the capital market and investment behavior analyses mitigates concerns about omitted correlated variables and alternative explanations, we cannot entirely rule out that other changes in bank regulation play into our findings. Notwithstanding these caveats, we believe that the collective evidence provided by the different sets of tests support the argument that our results are attributable to the removal of the AOCI filter. 


\section{REFERENCES}

Acharya, V. V., and S. G. Ryan, 2016. Banks' financial reporting and financial system stability. Journal of Accounting Research 54, 277-340.

Allen, F., and E. Carletti, 2008. Mark-to-market accounting and liquidity pricing. Journal of Accounting and Economics 45, 358-378.

American Bankers Association (ABA), Securities Industry and Financial Markets Association, The Financial Services Roundtable. 2012. Comment letter on proposals to comprehensively revise the regulatory capital framework for U.S. banking organizations, October 22, 2012.

Badertscher, B., J. Burks, and P. Easton, 2012. A convenient scapegoat: fair value accounting by commercial banks during the financial crisis. The Accounting Review 87, 59-90.

Basel Committee of Banking Supervision (BCBS), 2010. Basel III: A global regulatory framework for more resilient banks and banking systems, December 2010.

Basel Committee of Banking Supervision (BCBS), 2011. Basel III: A global regulatory framework for more resilient banks and banking systems, December 2010 (revised June 2011).

Beatty, A., 1995. The Effects of Fair Value Accounting on Investment Portfolio Management: How Fair Is It? Federal Reserve Bank of St. Louis (January/February).

Beatty, A., S. Chamberlain, and J. Magliolo, 1996. An empirical analysis of economic implications of fair value accounting for investment securities. Journal of Accounting and Economics 22, 43-77.

Beatty, A., B. Ke, and K. Petroni, 2002. Earnings management to avoid earnings declines across publicly and privately held banks. The Accounting Review 77, 547-570.

Beatty, A. and S. Liao, 2014. Financial accounting in the banking industry: A review of the empirical literature. Journal of Accounting and Economics 58, 339-383.

Bhat, G., R. Frankel, and X. Martin, 2011. Panaceas, Pandora's box, or placebo: feedback in bank holdings of mortgage-backed securities and fair value accounting. Journal of Accounting and Economics 52, 153-173.

Bischof, J., U. Brüggemann, and H. Daske, 2014. Fair value reclassifications of financial assets during the financial crisis. Working paper, University of Mannheim and Humboldt University of Berlin.

Bowen, R. M., and U. Khan, 2014. Market reactions to policy deliberations on fair value accounting and impairment rules during the financial crisis of 2008-2009. Journal of Accounting and Public Policy 33, 233-259. 
Dewatripont, M., and J. Tirole, 1994. The Prudential Regulation of Banks. MIT Press, Cambridge, MA.

Diamond, D., and R. Rajan, 2011. Fear of fire sales, illiquidity seeking, and credit freezes. Quarterly Journal of Economics 126, 557-591.

Ellul, A., Jotikasthira, C., Lundblad, C., and Y. Wang, 2014. Mark-to-Market accounting systematic risk: Evidence from the insurance industry. Economic Policy 29, 297-341.

Evans, M. E., L. Hodder, and P. E. Hopkins, 2014. The predictive ability of fair values for future financial performance of commercial banks and the relation of predictive ability to banks’ share prices. Contemporary Accounting Research 31, 13-44.

Federal Reserve, 2012. Federal Reserve Board extends comment period on three proposed capital rules rulemakings until October 22, 2012. Press Release. Published on August 8, 2012.

Federal Reserve (Final Rule), 2013. Regulatory capital rules: Regulatory capital, implementation of Basel III, capital adequacy, transition provisions, prompt corrective action, standardized approach for risk-weighted assets, market discipline and disclosure requirements, advanced approaches risk-based capital rule, and market risk capital rule.

Gulen, H., and M. Ion, 2015. Policy uncertainty and corporate investment. Review of Financial Studies, forthcoming.

Hodder, L., M. Kohlbeck, and M. McAnally, 2002. Accounting choices and risk management: SFAS 115 and U.S. bank holding companies. Contemporary Accounting Research 19, 225 270.

Kashyap, A. K., R. G. Rajan, and J. C. Stein, 2002. Banks as liquidity providers: An explanation for the coexistence of lending and deposit-taking. Journal of Finance 57, 3373.

Khan, U., 2010. Does Fair Value Accounting Contribute to Systemic Risk in the Banking Industry? Working Paper Columbia University.

Kim, D., and A. Santomero, 1988. Risk in Banking and Capital Regulation. Journal of Finance 35, 1219-1233.

Larcker, D. F., G. Ormazabal, and D. J. Taylor, 2011. The market reaction to corporate governance regulation. Journal of Financial Economics 101, 431-448.

Laux, C., 2012. Financial instruments, financial reporting, and financial stability. Accounting and Business Research 42, 1-22.

Laux, C., and C. Leuz., 2010. Did fair value accounting contribute to the Financial Crisis? Journal of Economic Perspectives 24, 93-118. 
Leuz, C., 2007. Was the Sarbanes Oxley Act of 2002 really this costly? A discussion of evidence from event returns and going-private decisions. Journal of Accounting and Economics 44, 146-165.

Lu, T., H. Sapra, and A. Subramaniam, 2012. Agency conflicts, prudential regulation, and marking to market. Working Paper. The University of Houston, The University of Chicago, Georgia State University.

Petersen, M., 2009. Estimating standard errors in finance panel datasets: comparing approaches. Review of Financial Studies 22, 435-480.

Plantin, G., H. Sapra, and H. S. Shin., 2008. Marking-to-Market: Panacea or Pandora's Box? Journal of Accounting Research 46, 435-460.

Sefcik, S.E. and R. Thompson, 1986. An approach to statistical inference in cross-sectional models with security abnormal returns as dependent variable. Journal of Accounting Research 24, 316-334

Stovall, N., 2012. Window of opportunity widens for banks to comment on Basel III. SNL Bank and Thrift Daily, 71611. Published on August 10, 2012.

The Clearing House, 2011. Letter to the Board of Governors of the Federal Reserve System, Federal Deposit Insurance Corporation, and Office of the Comptroller of Currency regarding the 'Treatment of Unrealized Gains and Losses Under the Basel III Capital Framework'.

Xie, B., 2015. Does fair value accounting exacerbate the pro-cyclicality of bank lending? Journal of Accounting Research, doi: 10.1111/1475-679X.12103. 
Figure 1: Empirical Approach to Identify Changes in Investment Behavior in Response to the Removal of the AOCI Filter

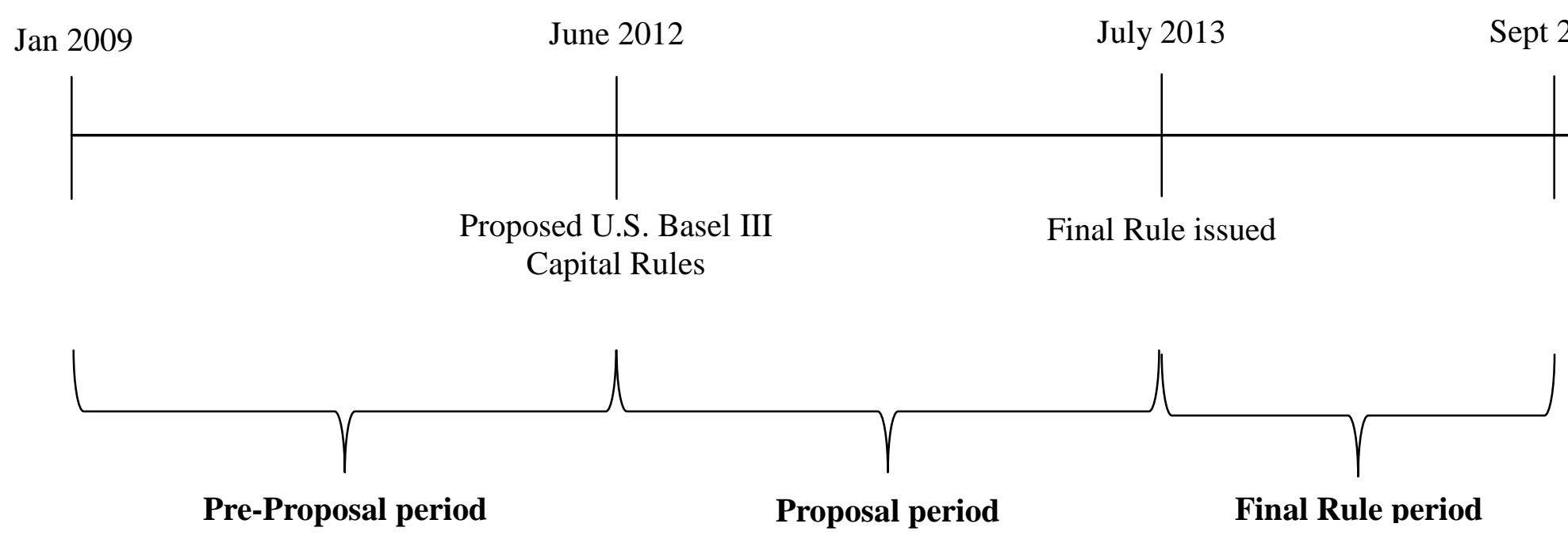

\begin{tabular}{|l|l|l|l|}
\hline Non-Basel Banks & Not affected & Not affected & Not affected \\
\hline $\begin{array}{l}\text { Non-Advanced } \\
\text { Approaches Banks }\end{array}$ & Not affected & Affected & Not affected \\
\hline $\begin{array}{l}\text { Advanced } \\
\text { Approaches Banks }\end{array}$ & Not affected & Affected & Affected \\
\hline
\end{tabular}


Figure 2: Net Purchases of Level 3 AFS securities

Panel A: Advanced Approaches Banks

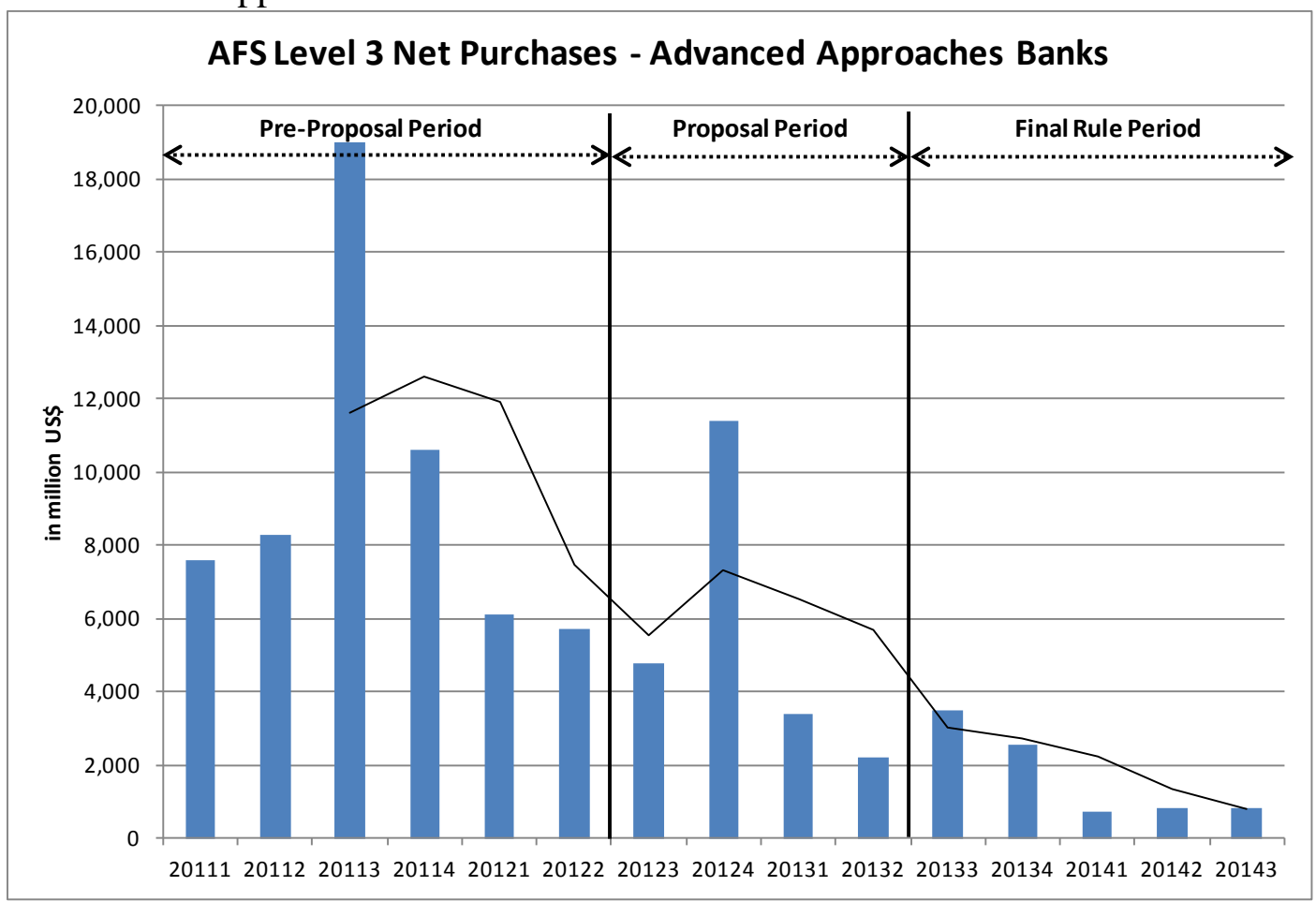

Panel B: Non-Advanced Approaches Banks

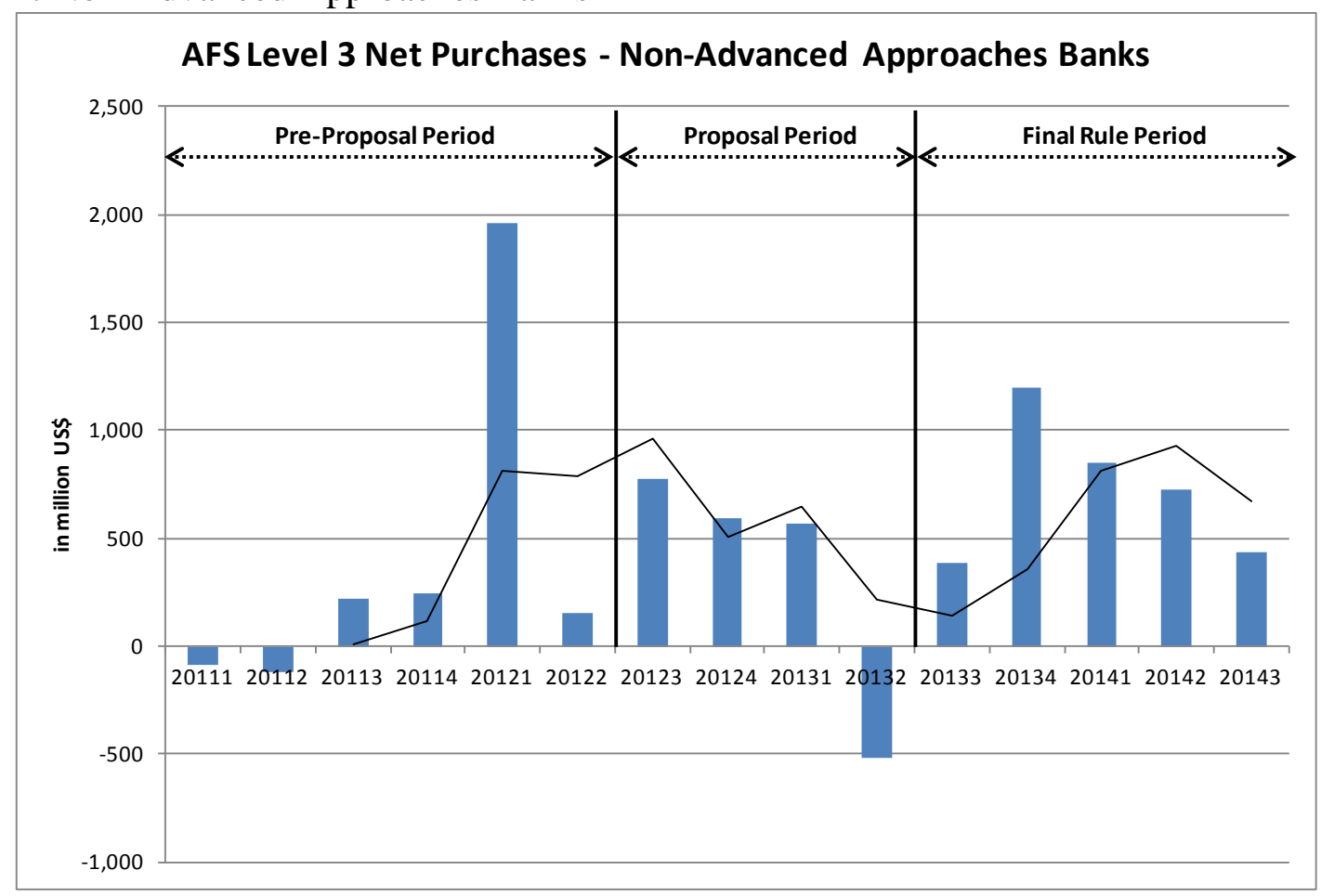

The figure illustrates time-series variation in net purchases for advanced approaches banks (Panel A) and non-advanced approaches banks (Panel B) over the three different time periods. The blue bars indicate the quarterly total net purchases summed over all banks in the given group (in million US\$), while the lines indicate three-quarter moving averages. 
Table 1:

Announcements concerning the removal of the AOCI filter

\begin{tabular}{|c|c|c|c|c|}
\hline $\begin{array}{l}\text { Event } \\
\text { No. }\end{array}$ & Date & Source & Headline/Description of article/announcement & $\begin{array}{c}\text { Increase (I)/ } \\
\text { Decrease (D)* }\end{array}$ \\
\hline 1 & December 16, 2010 & Bank for International Settlements & $\begin{array}{l}\text { Basel III rules text and results of the qualitative impact study issued by the Basel } \\
\text { Committee } \\
\text { The Basel Committee issued details of the global regulatory standards on bank capital } \\
\text { adequacy and liquidity. }\end{array}$ & ( \\
\hline 2 & June 1, 2011 & Bank for International Settlements & $\begin{array}{l}\text { Capital treatment for bilateral counterparty credit risk finalized by the Basel } \\
\text { Committee } \\
\text { The Basel Committee announced that it had completed a review and finalized the Basel } \\
\text { III capital treatment for counterparty credit risk in bilateral trades. }\end{array}$ & I \\
\hline 3 & June 7, 2012 & Federal Reserve Newswire & $\begin{array}{l}\text { Federal Reserve Board invites comment on three proposed rules intended to help } \\
\text { ensure banks maintain strong capital positions } \\
\text { Issue of Notice of Proposed Rule Making to remove the AOCI filter and invitation for } \\
\text { comment }\end{array}$ & I \\
\hline 4 & August 8, 2012 & Federal Reserve Newswire & $\begin{array}{l}\text { Federal Reserve Board extends comment period on three proposed capital rules } \\
\text { rulemakings until October 22, } 2012 \\
\text { Extension of comment period to allow interested persons more time to understand, } \\
\text { evaluate and prepare comments on the proposals }\end{array}$ & I \\
\hline 5 & August 10, 2012 & SNL Financial & $\begin{array}{l}\text { Window of opportunity widens for banks to comment on Basel III } \\
\text { Commenting on extension of comment period and that various organizations are } \\
\text { against removal of AOCI filter }\end{array}$ & $\mathrm{D}$ \\
\hline 6 & October 24, 2012 & SNL Financial & $\begin{array}{l}\text { OCC will take a 'very serious look' at Basel III impact on community banks } \\
\text { Possible exemption of community banks from Basel III proposals }\end{array}$ & $\mathrm{D}$ \\
\hline 7 & November 9, 2012 & Federal Reserve Newswire & $\begin{array}{l}\text { Agencies provide guidance on regulatory capital rulemakings } \\
\text { Delay in rule making process, which process would not be completed by January 1, } \\
2013 .\end{array}$ & I \\
\hline 8 & November 13, 2012 & Dow Jones/Wall Street Journal** & $\begin{array}{l}\text { Ignorance isn't bliss for banks } \\
\text { Expressed concern by small banks about the impact of Basel III rules - Independent } \\
\text { Community Bankers of America }\end{array}$ & $\mathrm{D}$ \\
\hline
\end{tabular}


Federal Reserve Governor Daniel Tarullo to discuss proposed capital rules, shadow banking in Senate hearing

Tarullo to discuss AOCI filter in Senate hearing

AOCI will affect community banks badly - Independent Community Bankers of America

Federal Reserve Board approves final rule to help ensure banks maintain strong

* The column lists whether the news in the article/announcement increased (I) or decreased (D) the likelihood that the AOCI filter is removed.

** The same news item was identified in both the Dow Jones Newswires and the Wall Street Journal.

This table contains the announcement dates used in assessing the share price reaction of banks and insurance companies to news about AOCI filter removal. Event dates 1 and 2 relate to the publication of the Basel III framework, while the other event dates were gathered from a search of Dow Jones Newswires, Wall Street Journal, Bloomberg, SNL Financial, Financial Times, and Federal Reserve Newswire for the term “AOCI filter” for the period January 6, 2012, to July 31, 2013. Only events deemed to convey new information were included in the analysis. 
Table 2:

Panel A: Details of the distribution of the sample used in analyzing the market reaction to AOCI filter news

\begin{tabular}{|c|c|c|c|c|}
\hline Banks & Frequency & Percent & $\begin{array}{l}\text { Cumulative } \\
\text { Frequency }\end{array}$ & $\begin{array}{c}\text { Cumulative } \\
\text { Percent }\end{array}$ \\
\hline Non-Advanced Approach & 257 & 96.98 & 257 & 96.98 \\
\hline Advanced Approach & 8 & 3.02 & 265 & 100 \\
\hline Insurers & Frequency & Percent & $\begin{array}{l}\text { Cumulative } \\
\text { Frequency }\end{array}$ & $\begin{array}{c}\text { Cumulative } \\
\text { Percent }\end{array}$ \\
\hline Insurers with total assets $<\$ 250 B$ & 78 & 95.12 & 78 & 95.12 \\
\hline Insurers with total assets $>\$ 250 \mathrm{~B}$ & 4 & 4.88 & 82 & 100 \\
\hline
\end{tabular}

Panel B: Details of the variables used in analyzing the market reaction to the AOCI filter news

Banks

\begin{tabular}{lcccccc}
\hline Variable & $\mathrm{N}$ & 25th Pctl & Mean & Median & 75th Pctl & Std Dev \\
\hline Rtn & 221,865 & -0.011 & 0.001 & 0.000 & 0.012 & 0.029 \\
Market_Rtn & 221,865 & -0.004 & 0.001 & 0.001 & 0.006 & 0.011 \\
5YR_Bond_Rtn & 221,865 & -0.003 & 0.003 & 0.003 & 0.009 & 0.010 \\
\hline
\end{tabular}

Insurers

\begin{tabular}{lcccccc}
\hline Variable & $\mathrm{N}$ & 25th Pctl & Mean & Median & 75th Pctl & Std Dev \\
\hline Rtn & 70,332 & -0.009 & 0.001 & 0.001 & 0.010 & 0.022 \\
Market_Rtn & 70,332 & -0.004 & 0.001 & 0.001 & 0.006 & 0.011 \\
5YR_Bond_Rtn & 70,332 & -0.003 & 0.003 & 0.003 & 0.009 & 0.010 \\
\hline
\end{tabular}

Panel A shows details of the distribution of the sample used in analyzing the market reaction to AOCI filter news over the period between Q2 2010 and Q3 2013. Advanced approaches banks include banks with mean total assets over the sample period greater than $\$ 250$ billion. Non-advanced approaches banks are those to which Basel III applies and total assets are greater than $\$ 500$ million and less than $\$ 250$ billion. A sample of 82 insurance companies is used as a benchmark for banks' stock market reaction. Panel B shows descriptive information about the variables used in analyzing market reactions to news events related to the AOCI filter removal. Rtn refers to the firm daily return including dividends. Market_Rtn refers to the CRSP value weighted. 5YR_Bond_Rtn refers to the return on a 5-year Treasury bill. 
Table 3:

Analyses of market reactions to news about the AOCI filter removal

Panel A: Analysis including all identified news events

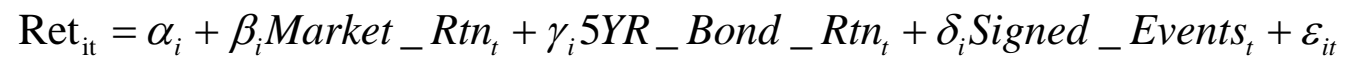

\begin{tabular}{|c|c|c|c|c|c|c|c|}
\hline \multirow[t]{2}{*}{ Variable } & \multicolumn{3}{|c|}{ Banks } & \multicolumn{3}{|c|}{ Insurers } & \multirow{2}{*}{ Difference } \\
\hline & Estimate & & t-value & Estimate & & t-value & \\
\hline Market_Rtn & 0.9488 & $* * *$ & 45.94 & 1.1712 & $* * *$ & 54.57 & \\
\hline 5YR_Bond_Rtn & -0.0452 & $* *$ & -2.56 & -0.0181 & & -1.10 & \\
\hline Signed_Events & 0.0014 & $* * *$ & 2.61 & 0.0000 & & 0.00 & 0.0014 \\
\hline Intercept & 0.0004 & $* *$ & 1.96 & 0.0002 & & 1.33 & \\
\hline R-squared & & 0.140 & & & 0.352 & & \\
\hline No. of observations & & 221,865 & & & 70,332 & & \\
\hline
\end{tabular}

Panel B: Analysis including regulatory news events only

$$
\text { Ret }_{\mathrm{it}}=\alpha_{i}+\beta_{i} \text { Market }_{-} \text {Rtn }_{t}+\gamma_{i} 5 Y R_{-} \text {Bond }_{-} \text {Rtn }_{t}+\delta_{i} \text { Signed }_{-} \operatorname{Re}_{t}+\varepsilon_{i t}
$$

\begin{tabular}{|c|c|c|c|c|c|c|c|c|}
\hline \multirow[t]{2}{*}{ Variable } & \multicolumn{3}{|c|}{ Banks } & \multicolumn{3}{|c|}{ Insurers } & \multicolumn{2}{|c|}{ Difference } \\
\hline & Estimate & & t-value & Estimate & & t-value & & \\
\hline Market_Rtn & 0.9485 & $* * *$ & 45.94 & 1.1712 & $* * *$ & 54.6 & & \\
\hline 5YR_Bond_Rtn & -0.0457 & $* *$ & -2.59 & -0.0175 & & -1.06 & & \\
\hline Signed_Reg & 0.0019 & $* * *$ & 2.73 & -0.0007 & & -0.89 & 0.0026 & $* * *$ \\
\hline Intercept & 0.0004 & $* *$ & 2.11 & 0.0002 & & 1.25 & & \\
\hline R-squared & & 0.140 & & & 0.352 & & & \\
\hline No. of observations & & 221,865 & & & 70,332 & & & \\
\hline
\end{tabular}

This table shows the results of analyses of market reactions to news events about the AOCI filter removal. Panel A shows the results for an analysis including all news events identified in Table 1, while Panel B shows the results for regulatory news events only. Market_Rtn is the CRSP value weighted return; 5YR_Bond_Rtn is the return on the 5year Treasury bill; Signed_Events is an indicator variable that takes the value of 1 for event windows around events that decrease the probability of AOCI filter removal, takes the value of -1 for event windows around events that increase the likelihood that the AOCI filter is removed, and 0 otherwise; and Signed_Reg is computed similar to Signed_Events but for regulatory news events (Events 1, 2, 3, 4, 7, and 12) only. Event windows start one day before and end one day after the event date. The sample consists of daily market data for the period Q2 2010 to Q3 2013, comprising 265 banks and 82 insurance firms. Difference shows the results of a chi-squared test for differences in coefficient estimates. Standard errors are clustered by date. *, **, and *** denote a $10 \%, 5 \%$, and $1 \%$ level of significance, respectively. 
Table 4:

Analysis of market reactions to individual news about the AOCI removal

$$
\text { Ret }_{i t}=\alpha_{i}+\beta_{i} \text { Market_Rtn }+\gamma_{i} 5 Y R_{-} \text {Bond } \_R t n_{t}+\sum_{k=1}^{K} \delta_{i k} \text { Events }_{k t}+\varepsilon_{i t}
$$

\begin{tabular}{|c|c|c|c|c|c|c|c|c|c|}
\hline \multirow{2}{*}{ Variable } & \multirow{2}{*}{$\begin{array}{l}\text { Expected } \\
\text { sign }\end{array}$} & \multicolumn{3}{|c|}{ Banks } & \multicolumn{3}{|c|}{ Insurers } & \multicolumn{2}{|c|}{ Difference } \\
\hline & & Estimate & & t-value & Estimate & & t-value & & \\
\hline Market_Rtn & & 0.9488 & $* * *$ & 45.71 & 1.1718 & $* * *$ & 54.27 & & \\
\hline 5YR_Bond_Rtn & & -0.0441 & $* *$ & -2.45 & -0.0180 & & -1.07 & & \\
\hline Event_1 & - & -0.0010 & & -0.67 & -0.0008 & & -0.61 & -0.0002 & \\
\hline Event_2 & - & -0.0021 & $*$ & -1.86 & 0.0018 & $* *$ & 2.18 & -0.0039 & $* * *$ \\
\hline Event_3 & - & -0.0017 & & -0.76 & 0.0002 & & 0.08 & -0.0019 & \\
\hline Event_4 & - & -0.0010 & & -1.12 & 0.0012 & $* * *$ & 2.72 & -0.0022 & $* * *$ \\
\hline Event_5 & + & -0.0008 & & -0.36 & -0.0001 & & -0.04 & -0.0007 & \\
\hline Event_6 & + & 0.0040 & $* * *$ & 3.28 & 0.0034 & $* * *$ & 4.52 & 0.0006 & \\
\hline Event_7 & - & 0.0013 & * & 1.85 & 0.0026 & $* *$ & 2.1 & -0.0013 & \\
\hline Event_8 & + & -0.0025 & $*$ & -1.89 & -0.0023 & & -1.06 & -0.0002 & \\
\hline Event_9 & + & -0.0001 & & -0.27 & 0.0003 & & 0.12 & -0.0004 & \\
\hline Event_10 & + & 0.0029 & $* *$ & 2.12 & -0.0007 & & -0.43 & 0.0036 & $* * *$ \\
\hline Event_11 & + & 0.0013 & $*$ & 1.86 & 0.0014 & $* * *$ & 6.08 & -0.0001 & \\
\hline Event_12 & + & 0.0052 & $* * *$ & 4.23 & 0.0001 & & 0.03 & 0.0051 & $* * *$ \\
\hline Intercept & & 0.0004 & * & 1.82 & 0.0002 & & 1.13 & & \\
\hline R-squared & & & & 0.140 & & & 0.353 & & \\
\hline No. of observations & & & & 21,865 & & & 70,332 & & \\
\hline
\end{tabular}

This table shows the results of the regression of bank and insurance stock returns, respectively, on the CRSP value weighted market return (Market_Rtn), the return on 5-year Treasury bill (5YR_Bond_Rtn), and event indicator variables (Event_1 - Event_12). The sample consists of daily market data for the period Q2 2010 to Q3 2013, comprising 265 banks and 82 insurance firms. Event_1 - Event_12 refer to news events relevant to the AOCI filter removal and are described in Table 1. Event_1 - Event_12 take the value of 1 on the 3-day event windows around the date when the actual event takes place, and 0 otherwise. Difference shows the results of a chi-squared test for differences in coefficient estimates. Standard errors are clustered by date. *, **, and *** denote a $10 \%, 5 \%$, and $1 \%$ level of significance, respectively. 
Table 5:

Descriptive statistics for all banks in the cross-sectional analysis

\begin{tabular}{lrrrrrr}
\hline Variable & N & 25th Pctl & \multicolumn{1}{c}{ Mean } & Median & 75th Pctl & Std Dev \\
\hline AFS & 232 & 0.118 & 0.189 & 0.170 & 0.247 & 0.099 \\
Maturity & 232 & 0.149 & 0.282 & 0.252 & 0.377 & 0.188 \\
Exposure & 232 & -0.004 & 0.001 & 0.000 & 0.005 & 0.008 \\
URGL & 232 & 0.001 & 0.002 & 0.002 & 0.003 & 0.002 \\
Level3AFS & 232 & 0.000 & 0.013 & 0.000 & 0.007 & 0.035 \\
Tier1 & 232 & 0.086 & 0.099 & 0.096 & 0.108 & 0.022 \\
Vola_Tier1 & 232 & 0.047 & 0.098 & 0.074 & 0.113 & 0.081 \\
Debt & 232 & 0.193 & 0.257 & 0.248 & 0.308 & 0.096 \\
Size & 232 & 13.938 & 15.100 & 14.700 & 15.785 & 1.643 \\
\hline
\end{tabular}

The sample comprises 232 banks with stock return and financial statement data available on CRSP and SNL Financial, respectively. The table shows descriptive statistics for the variables used in both the two-stage cross-sectional regression and the Sefcik and Thompson (1986) methodology. All variables are the means for the quarterly observations for each sample firm over the period from Q2 2010 to Q3 2013. AFS is the amortized cost value of AFS securities scaled by total assets. Maturity is total debt securities with maturity longer than 3 years scaled by total securities. Exposure is the coefficient on change in U.S. Federal Funds Rate in a regression of bank stock returns on market return and change in U.S. Federal Funds Rate. URGL is calculated as net unrealized gains scaled by total assets. Level3AFS is the dollar value of Level 3 AFS securities scaled by the amortized cost value of AFS securities. Tier1 is Tier 1 capital scaled by total assets. Vola_Tier1 is the standard deviation coefficient calculated as the standard deviation of Tier 1 capital over the sample period scaled by mean Tier 1 capital. Debt is non-deposit liabilities scaled by total assets. Size is the logarithm of total assets. 
Table 6:

Panel A: Results of the two-stage cross-sectional regression

\begin{tabular}{lcccc}
\hline \multirow{2}{*}{ Variable } & $\begin{array}{c}\text { Expected } \\
\text { Sign }\end{array}$ & \multicolumn{2}{c}{ Signed_Events } \\
\cline { 3 - 5 } & & Estimate & t-value \\
\hline & & & & \\
AFS & + & -0.004 & -1.64 \\
Maturity & + & 0.001 & & 0.9 \\
Exposure & + & 0.040 & & 1.64 \\
URGL & + & 0.294 & $* * *$ & 2.83 \\
Level3AFS & $?$ & 0.000 & & -0.02 \\
Tier1 & - & -0.024 & $* *$ & -2.59 \\
Vola_Tier1 & + & 0.003 & & 1.15 \\
Debt & $?$ & 0.000 & & 0.11 \\
Size & $?$ & 0.000 & & -0.87 \\
Intercept & & 0.005 & $*$ & 1.89 \\
& & & & \\
\hline R-squared & & & & \\
No. of observations & & & & \\
\hline
\end{tabular}

Panel B: Results of the Sefcik \& Thompson (1986) methodology

\begin{tabular}{|c|c|c|c|c|}
\hline \multirow{2}{*}{ Variable } & \multirow{2}{*}{$\begin{array}{l}\text { Expected } \\
\text { Sign }\end{array}$} & \multicolumn{3}{|c|}{ Signed_Events } \\
\hline & & Estimate & & t-value \\
\hline AFS & + & -0.004 & & -1.21 \\
\hline Maturity & + & 0.001 & & 0.62 \\
\hline Exposure & + & 0.040 & & 0.67 \\
\hline URGL & + & 0.294 & $*$ & 1.65 \\
\hline Level3AFS & $?$ & 0.000 & & -0.02 \\
\hline Tier1 & - & -0.024 & & -1.43 \\
\hline Vola_Tier1 & + & 0.003 & & 0.44 \\
\hline Debt & $?$ & 0.000 & & 0.08 \\
\hline Size & $?$ & 0.000 & & -0.37 \\
\hline Intercept & & 0.005 & & 0.84 \\
\hline No. of observations & & \multicolumn{3}{|c|}{881} \\
\hline
\end{tabular}


Panel C: Bootstrapping analysis

\begin{tabular}{|c|c|c|c|}
\hline Variable & $\begin{array}{c}\text { Expected Sign } \\
{[\beta-E(\beta)]}\end{array}$ & $\beta$ & $E(\beta)$ \\
\hline \multirow[t]{2}{*}{ AFS } & + & -0.004 & 0.001 \\
\hline & & \multicolumn{2}{|c|}{$[-36.52] * * *$} \\
\hline \multirow[t]{2}{*}{ Maturity } & + & 0.001 & 0.000 \\
\hline & & \multicolumn{2}{|c|}{$[28.60]^{* * *}$} \\
\hline \multirow[t]{2}{*}{ Exposure } & + & 0.040 & 0.004 \\
\hline & & \multicolumn{2}{|c|}{$[24.50]^{* * *}$} \\
\hline \multirow[t]{2}{*}{ URGL } & + & 0.294 & 0.027 \\
\hline & & \multicolumn{2}{|c|}{$[52.68]^{* * *}$} \\
\hline \multirow[t]{2}{*}{ Level3AFS } & $?$ & 0.000 & 0.001 \\
\hline & & \multicolumn{2}{|c|}{$[-4.51]^{* * *}$} \\
\hline \multirow[t]{2}{*}{ Tier1 } & - & -0.024 & 0.003 \\
\hline & & \multicolumn{2}{|c|}{$[-66.18]^{* * *}$} \\
\hline \multirow[t]{2}{*}{ Vola_Tier1 } & + & 0.003 & 0.000 \\
\hline & & \multicolumn{2}{|c|}{$[16.14]^{* * *}$} \\
\hline \multirow[t]{2}{*}{ Debt } & ? & 0.000 & 0.000 \\
\hline & & \multicolumn{2}{|c|}{$[5.65]^{* * *}$} \\
\hline \multirow[t]{2}{*}{ Size } & $?$ & 0.005 & 0.000 \\
\hline & & \multicolumn{2}{|c|}{$[-18.53]^{* * *}$} \\
\hline
\end{tabular}

Panel A shows the results of the two-stage cross-sectional regression, where the dependent variable is the coefficient on Signed_Events that is obtained from firm-specific regressions of bank stock returns on the value weighted market return, 5-year Treasury bill return, and the Signed_Events indicator. Panel B shows the results of the Sefcik and Thompson (1986) methodology. In Panel A we have 232 observations as we have one observation for each of the sample firms, while in Panel B we have 881 observations, since by construction the Sefcik and Thompson (1986) methodology produces weighted returns for each trading day in the sample period (i.e., 881 trading days). Independent variables are defined in Table 5. In Panel C we show the result for our bootstrapping analysis where $\beta$ is the estimate from the event date regression (reported in Panel $\mathrm{A}$ ), and $E(\beta)$ is the average coefficient resulting from repeating the same regression 1000 times for non-event date groups. Each non-event date group consists of 12 randomly selected three-day, non-event time windows. In randomly selecting these 12 three-day, non-event windows, we mimic the year-by-year distribution and the signs of our events from Q2 2010 to Q3 2013. We then test whether estimated coefficients for the event days $(\beta)$ are significantly different from the average of the 1000 estimated coefficients for the non-event days $(E[\beta])$ using the empirical distribution of $\beta$ on non-event days to compute the standard error of $E[\beta]$. t-statistics for a (two-tailed) t-test for the null $\beta=E(\beta)$ appear in brackets. *, **, and $* * *$ denote a $10 \%, 5 \%$ and $1 \%$ level of significance, respectively. 
Table 7:

Descriptive statistics for the multivariate analysis of banks’ investment behavior

Panel A: Observations for all banks in the Pre-Proposal period

\begin{tabular}{lrrrrrr}
\hline & Mean & $\mathrm{p} 25$ & $\mathrm{p} 50$ & $\mathrm{p} 75$ & $\mathrm{sd}$ & $\mathrm{N}$ \\
\cline { 2 - 7 } $\begin{array}{l}\text { Dependent variables } \\
\text { Weighted_Sec }\end{array}$ & & & & & & \\
AFS_Sec & 1.748 & 0.685 & 1.346 & 2.354 & 1.607 & 3,384 \\
Level3AFS & 0.912 & 0.912 & 0.998 & 1.000 & 0.177 & 3,384 \\
Control variables & 0.029 & 0.000 & 0.005 & 0.032 & 0.069 & 1,719 \\
URGL & & & & & & \\
Size & 0.002 & 0.000 & 0.001 & 0.003 & 0.003 & 3,384 \\
Tier1 & 14.923 & 13.740 & 14.524 & 15.680 & 1.683 & 3,384 \\
Debt & 0.096 & 0.084 & 0.094 & 0.106 & 0.025 & 3,384 \\
Deposits & 0.255 & 0.194 & 0.244 & 0.303 & 0.096 & 3,384 \\
ROA & 0.644 & 0.591 & 0.652 & 0.709 & 0.102 & 3,384 \\
& 0.001 & 0.000 & 0.002 & 0.002 & 0.005 & 3,384 \\
\hline
\end{tabular}

Panel B: Observations for all banks in the period after the issue of the Proposal but before the issue of the Final Rule

\begin{tabular}{lrrrrrr}
\hline & Mean & $\mathrm{p} 25$ & $\mathrm{p} 50$ & $\mathrm{p} 75$ & $\mathrm{sd}$ & $\mathrm{N}$ \\
\cline { 2 - 7 } Dependent variables & & & & & & \\
Weighted_Sec & 1.961 & 0.839 & 1.493 & 2.701 & 1.714 & 1,006 \\
AFS_Sec & 0.892 & 0.846 & 0.999 & 1.000 & 0.194 & 1,006 \\
Level3AFS & 0.021 & 0.000 & 0.004 & 0.020 & 0.045 & 540 \\
& & & & & & \\
Control variables & & & & & & \\
URGL & 0.002 & 0.000 & 0.002 & 0.004 & 0.003 & 1,006 \\
Size & 14.962 & 13.809 & 14.546 & 15.709 & 1.691 & 1,006 \\
Tier1 & 0.100 & 0.087 & 0.098 & 0.111 & 0.024 & 1,006 \\
Debt & 0.260 & 0.196 & 0.258 & 0.313 & 0.100 & 1,006 \\
Deposits & 0.634 & 0.578 & 0.637 & 0.699 & 0.103 & 1,006 \\
ROA & 0.002 & 0.001 & 0.002 & 0.003 & 0.003 & 1,006 \\
\hline
\end{tabular}


Panel C: Observations for all banks in the period after the issue of the Final Rule

\begin{tabular}{lrrrrrr}
\hline & Mean & p25 & p50 & p75 & sd & N \\
\cline { 2 - 6 } Dependent variables & & & & & & \\
Weighted_Sec & 1.961 & 0.834 & 1.557 & 2.756 & 1.650 & 1,111 \\
AFS_Sec & 0.853 & 0.755 & 0.980 & 1.000 & 0.213 & 1,111 \\
Level3AFS & 0.020 & 0.000 & 0.002 & 0.018 & 0.048 & 587 \\
& & & & & \\
Control variables & & & & & \\
URGL & -0.000 & -0.001 & 0.000 & 0.001 & 1.003 & 1,111 \\
Size & 15.030 & 13.827 & 14.644 & 15.811 & 1,111 \\
Tier1 & 0.100 & 0.088 & 0.099 & 0.111 & 0.022 & 1,111 \\
Debt & 0.274 & 0.204 & 0.272 & 0.331 & 0.099 & 1,111 \\
Deposits & 0.620 & 0.559 & 0.621 & 0.684 & 0.101 & 1,111 \\
ROA & 0.002 & 0.002 & 0.002 & 0.003 & 0.002 & 1,111 \\
\hline
\end{tabular}

The sample comprises firm-quarter observations for 259 banks, representing eight advanced approaches banks, 224 non-advanced approaches banks, and 27 Non-Basel banks (total assets $<\$ 500$ million), for the sample period between Q1 2009 and Q3 2014. Weighted_Sec is calculated as ((Debt Securities with maturity 3-5 years/total securities)*3+(Debt Securities with maturity 5-15 years/total securities)*5+(Debt Securities with maturity $>15$ years/total securities)*15). AFS_Sec is the amortized cost value of AFS securities scaled by the amortized cost value of total investment securities (i.e., the sum of available-for-sale and held-to-maturity securities). Level3AFS is the fair value of AFS securities that are measured using unobservable inputs scaled by the amortized cost value of AFS securities; URGL is unrealized gains and losses scaled by total assets; Size is logarithm of total assets; Tier1 is Tier1 capital scaled by total assets; Debt is non-deposit liabilities scaled by total assets; Deposits is deposits scaled by total assets; $R O A$ is return on assets calculated as net income before extraordinary items scaled by total assets. 
Table 8:

Results for changes in investment behavior

$$
\begin{aligned}
& \text { Investment }_{\mathrm{it}}=\alpha_{0}+\beta_{1} \text { Proposal } * \text { NonAdvApproach }+\beta_{2} \text { Final_Rule*NonAdvApproach }+ \\
& +\beta_{3} \text { Proposal } * \text { AdvApproach }+\beta_{4} \text { Final_Rule*AdvApproac } \mathrm{h}+\text { Controls }+ \text { Firm Fixed effects }+ \\
& + \text { Quarter }- \text { year Fixed effects }+\varepsilon_{i t}
\end{aligned}
$$

\begin{tabular}{|c|c|c|c|c|c|c|c|}
\hline & & \multicolumn{2}{|c|}{$\begin{array}{c}\text { (1) } \\
\text { Weighted_Sec }\end{array}$} & \multicolumn{2}{|c|}{$\begin{array}{c}(2) \\
\text { AFS_Sec }\end{array}$} & \multicolumn{2}{|c|}{$\begin{array}{c}\text { (3) } \\
\text { Level3AFS }\end{array}$} \\
\hline & & Coefficient & t-stat. & Coefficient & t-stat. & Coefficient & t-stat. \\
\hline Proposal*NonAdvApproach & (1) & 0.248 & 0.81 & 0.010 & 0.46 & $-0.016^{* * *}$ & -2.67 \\
\hline Final Rule*NonAdvApproach & (2) & 0.114 & 0.37 & 0.006 & 0.18 & -0.018 & -1.60 \\
\hline Proposal*AdvApproach & (3) & -0.049 & -0.13 & -0.039 & -0.81 & $-0.035 * * *$ & -4.65 \\
\hline Final Rule*AdvApproach & (4) & -0.110 & -0.25 & -0.059 & -1.15 & $-0.049 * * *$ & -3.32 \\
\hline \multicolumn{8}{|l|}{ F-test for differences [p-value]: } \\
\hline$(1)=(3)$ & (5) & {$[0.210]$} & & [0.257] & & {$[0.002]$} & \\
\hline$(2)=(4)$ & (6) & {$[0.520]$} & & {$[0.120]$} & & {$[0.005]$} & \\
\hline$(3)=(4)$ & (7) & {$[0.757]$} & & {$[0.478]$} & & {$[0.142]$} & \\
\hline ROA & & -4.418 & -0.96 & 0.023 & 0.05 & 0.606 & 0.82 \\
\hline Deposits & & -3.140 & -0.83 & 0.504 & 1.36 & 0.057 & 0.28 \\
\hline URGL & & $-33.220 * *$ & -2.27 & $4.758^{* * *}$ & 3.23 & -0.837 & -1.03 \\
\hline Tier 1 Capital & & -7.656 & -1.59 & 0.259 & 0.67 & -0.146 & -0.62 \\
\hline Debt & & -4.543 & -1.19 & 0.459 & 1.30 & -0.051 & -0.28 \\
\hline Size & & -0.327 & -1.00 & -0.036 & -1.29 & 0.012 & 0.81 \\
\hline Weighted_Sec & & & & $-0.007 *$ & -1.69 & -0.003 & -0.62 \\
\hline Firm fixed effects & & Yes & & Yes & & Yes & \\
\hline Quarter-Year fixed effects & & Yes & & Yes & & Yes & \\
\hline Adjusted R-squared & & 0.043 & & 0.073 & & 0.055 & \\
\hline Observations & & 5,501 & & 5,501 & & 2,846 & \\
\hline
\end{tabular}

The sample comprises firm-quarter observations for 259 banks, representing eight advanced approaches banks, 224 non-advanced approaches banks, and 27 Non-Basel banks (total assets $<\$ 500$ million), for the sample period between Q1 2009 and Q3 2014. Proposal is an indicator variable that takes the value of 1 for firm-quarter observations after the proposal was issued but before the issuance of the Final Rule, i.e. from the third quarter of 2012 to the second quarter of 2013, and 0 otherwise. Final_Rule is an indicator variable that takes the value of 1 for firm-quarter observations after the Final Rule was published, i.e., from the third quarter of 2013, and 0 otherwise. NonAdvApproach is an indicator variable that takes the value of 1 for non-advanced approaches banks, and 0 otherwise. AdvApproach is an indicator variable that takes the value of 1 for advanced approaches banks, and 0 otherwise. All other variables are defined in Table 7. We include firm fixed and quarter-year fixed effects, but do not report the coefficients. t-statistics are based on standard errors clustered at the bank level. We also report $p$ values from Wald tests assessing the significance of differences in treatment effects. *, ** and *** denote a $10 \%$, $5 \%$ and $1 \%$ level of significance, respectively. 
Table 9:

Changes in the proportion of illiquid (Level 3) trading securities

\begin{tabular}{|c|c|c|c|}
\hline & & \multicolumn{2}{|c|}{ Level3Trading } \\
\hline & & Coefficient & t-stat. \\
\hline Proposal*AdvApproach & (1) & -0.025 & -0.71 \\
\hline Final Rule*AdvApproach & (2) & -0.045 & -0.99 \\
\hline \multicolumn{4}{|c|}{ F-test for differences [p-value]: } \\
\hline$(1)=(2)$ & (3) & {$[0.514]$} & \\
\hline ROA & & 3.533 & 1.33 \\
\hline Deposits & & 2.331 & 1.01 \\
\hline URGL & & $11.550 * *$ & 2.31 \\
\hline Tier 1 Capital & & 1.452 & 0.55 \\
\hline Debt & & 2.363 & 1.01 \\
\hline Size & & -0.224 & -1.52 \\
\hline Weighted_Sec & & -0.055 & -1.53 \\
\hline Firm fixed effects & & Yes & \\
\hline Quarter-year fixed effects & & Yes & \\
\hline Adjusted R-squared & & 0.191 & \\
\hline Observations & & 658 & \\
\hline
\end{tabular}

The sample comprises firm-quarter observations for 34 banks, representing eight advanced approaches banks and 26 non-advanced approaches banks, for the sample period between Q1 2009 and Q3 2014. The sample includes only banks that had exposure to Level 3 trading securities during the sample period. The dependent variable Level3Trading is calculated as Level 3 trading securities scaled by total trading securities. AdvApproach is an indicator variable that takes the value of 1 for advanced approaches banks, and 0 otherwise. All other variables are defined in Table 7. The analysis includes firm fixed and quarter-year fixed effects. t-statistics are based on standard errors clustered at the bank level. We also report $p$-values from Wald tests assessing the significance of differences in treatment effects. $*$, **, and $* * *$ denote a $10 \%, 5 \%$, and $1 \%$ level of significance, respectively. 
Table 10:

Analysis of Level 3 rollforward activity data

Panel A: Descriptive statistics of purchases, sales, and net transfers of Level 3 AFS securities

\begin{tabular}{lrrrrrrrrr}
\hline & \multicolumn{2}{c}{ Non-Advanced Approaches Banks } & & \multicolumn{3}{c}{ Advanced Approaches Banks } \\
& Pre-Proposal & Proposal & Final Rule & & Pre-Proposal & Proposal & Final Rule \\
\cline { 2 - 4 } & 0.0014 & 0.0012 & 0.0053 & & 0.0072 & 0.0039 & 0.0015 \\
AFS L3 Purchases & 0.0015 & 0.0084 & 0.0004 & & 0.0012 & 0.0013 & 0.0003 \\
AFS L3 Sales & -0.0001 & -0.0072 & 0.0049 & & 0.0060 & 0.0026 & 0.0012 \\
AFS L3 Net Purchases & & & & & & & -0.0027 & -0.0057 & -0.0014 \\
\hline
\end{tabular}


(1)

(2)

\begin{tabular}{|c|c|c|c|c|c|}
\hline & & AFS L3 Ne & lases & AFS L3 Ne & sfers \\
\hline & & Coefficient & t-stat. & Coefficient & t-stat. \\
\hline Proposal & (1) & -0.008 & -0.87 & 0.001 & 1.41 \\
\hline Final Rule & (2) & $0.009 *$ & 1.94 & 0.001 & 1.42 \\
\hline Proposal*AdvApproach & (3) & 0.003 & 0.37 & -0.003 & -1.02 \\
\hline Final Rule*AdvApproach & (4) & $-0.011 * * *$ & -2.99 & 0.002 & 1.45 \\
\hline F-test for differences [p-va & & & & & \\
\hline$(1)=(3)$ & (5) & {$[0.531]$} & & {$[0.194]$} & \\
\hline$(2)=(4)$ & (6) & {$[0.010]$} & & {$[0.653]$} & \\
\hline ROA & & -1.471 & -0.84 & -0.185 & -0.41 \\
\hline Deposits & & 0.003 & 0.02 & 0.079 & 1.56 \\
\hline 10YR_Bond_Rtn & & -0.002 & -0.92 & 0.000 & 0.51 \\
\hline URGL & & 0.138 & 0.21 & 0.149 & 0.94 \\
\hline Tier 1 Capital & & -0.563 & -0.98 & $-0.211^{* * *}$ & -2.86 \\
\hline Debt & & -0.062 & -0.34 & 0.073 & 1.41 \\
\hline Size & & -0.015 & -0.81 & $-0.011^{* *}$ & -2.00 \\
\hline Firm fixed effects & & Yes & & Yes & \\
\hline Quarter-year fixed effects & & No & & No & \\
\hline Adjusted R-squared & & 0.062 & & 0.162 & \\
\hline Observations & & 270 & & 270 & \\
\hline
\end{tabular}

The sample comprises firm-quarter observations for 18 banks, representing eight advanced approaches banks and 10 non-advanced approaches banks for the period between Q1 2011 and Q3 2014. Panel A provides the mean values of purchases, sales, and net transfers of Level 3 securities from/into other fair value levels. Panel B reports regression results for two dependent variables: (1) AFS L3 Net Purchases and (2) AFS L3 Net Transfers. AFS L3 Purchases is quarterly purchases of Level 3 AFS securities scaled by the amortized cost value of total AFS securities. AFS L3 Sales is quarterly sales of Level 3 AFS securities scaled by the amortized cost value of total AFS securities. AFS L3 Net Purchases is calculated as AFS L3 Purchases minus AFS L3 Sales. AFS L3 Net Transfers is calculated as transfers into minus transfers out of Level 3 AFS securities to other fair value levels. Proposal is an indicator variable that takes the value of 1 for firm-quarter observations after the proposal was issued but before the issuance of the Final Rule, i.e., from the third quarter of 2012 to the second quarter of 2013, and 0 otherwise. Final_Rule is an indicator variable that takes the value of 1 for firm-quarter observations after the Final Rule was published, i.e., from the third quarter of 2013, and 0 otherwise. AdvApproach is an indicator variable that takes the value of 1 for advanced approaches banks, and 0 otherwise. 10YR_Bond_Rtn is the return on 10-year Treasury bills. All other variables are defined in Table 7. Firm fixed effects are included. t-statistics are based on heteroscedasticity robust standard errors. We also report $p$-values from Wald tests assessing the significance of differences in treatment effects. *, **, and ${ }^{* * *}$ denote a $10 \%, 5 \%$, and $1 \%$ level of significance, respectively. 